\title{
Estrogens and atherosclerosis: insights from animal models and cell systems
}

\author{
Jerzy-Roch Nofer ${ }^{1,2}$ \\ ${ }^{1}$ Center for Laboratory Medicine, University Hospital Münster, Albert Schweizer Campus 1, Gebäude A1, 48129 Münster, Germany \\ ${ }^{2}$ Department of Medicine, Endocrinology, Metabolism and Geriatrics, University of Modena and Reggio Emilia, Modena, Italy \\ (Correspondence should be addressed to J-R Nofer at Center for Laboratory Medicine, University Hospital Münster; Email: nofer@uni-muenster.de)
}

\begin{abstract}
Estrogens not only play a pivotal role in sexual development but are also involved in several physiological processes in various tissues including vasculature. While several epidemiological studies documented an inverse relationship between plasma estrogen levels and the incidence of cardiovascular disease and related it to the inhibition of atherosclerosis, an interventional trial showed an increase in cardiovascular events among postmenopausal women on estrogen treatment. The development of atherosclerotic lesions involves complex interplay between various pro- or anti-atherogenic processes that can be effectively studied only in vivo in appropriate animal models. With the advent of genetic engineering, transgenic mouse models of atherosclerosis have supplemented classical dietary cholesterolinduced disease models such as the cholesterol-fed rabbit. In the last two decades, these models were widely applied along with in vitro cell systems to specifically investigate the influence of estrogens on the development of early and advanced atherosclerotic lesions. The present review summarizes the results of these studies and assesses their contribution toward better understanding of molecular mechanisms underlying anti- and/or pro-atherogenic effects of estrogens in humans.
\end{abstract}

Journal of Molecular Endocrinology (2012) 48, R13-R29

\section{Introduction}

Sexual hormones are intimately involved in the pathogenesis of atherosclerosis. The strikingly lower incidence of myocardial infarction (MI) in premenopausal women than in men in the same age group, together with the dramatic increase in coronary risk after menopause is strongly suggestive of an important role of estrogen levels in the etiology of MI in women (Lerner \& Kannel 1986, Pérez-López et al. 2009). Studies on males with defective estrogen action add further support to the notion that these hormones exert potent atheroprotective effects. Actually, accelerated development of atherosclerosis has been observed in male subjects deficient in $\mathrm{P} 450$ aromatase, an enzyme that converts androgens to estrogens, and characterized by estradiol $\left(\mathrm{E}_{2}\right)$ levels below the detection limit (Maffei et al. 2004). More importantly, estrogen treatment in aromatase-deficient subjects reversed atherosclerotic changes in the carotid artery. While the above results provide a strong argument for the atheroprotective effects of estrogens, they are in a remarkable contradiction to other data suggesting that, under certain circumstances, these hormones promote the development of atherosclerosis. First, epidemiological studies examining the efficacy of menopausal hormone therapy demonstrated that $\mathrm{E}_{2}$ applied together with progestins increases coronary risk in postmenopausal women both with and without clinically established coronary heart disease (Hulley et al. 1998, Rossouw et al. 2002). Secondly, no or even positive correlation between plasma estrogen levels and atherosclerosis has been found in male subjects with intact $\mathrm{E}_{2}$ synthesis (The Coronary Drug Project Research Group 1970, Muller et al. 2004). In addition, administration of $\mathrm{E}_{2}$ in such males has been reported to increase the risk of MI and stroke. While reasons for these profound discrepancies remain obscure, they may be related to the following:

- divergent estrogen levels - various treatment regimens have been used in both clinical and animal studies for estrogen substitution. It cannot, therefore, be excluded that estrogens exert both anti- and pro-atherogenic effects depending on actual plasma hormone concentrations; 
- distinct estrogen receptors - estrogens act via distinct receptors including nuclear receptors estrogen receptor $\alpha(\mathrm{ER} \alpha)$ and $\beta(\mathrm{ER} \beta)$ as well as the recently identified plasma membrane-bound and $\mathrm{G}$ proteincoupled GPR30 (GPER). The exact involvement of these receptors in processes related to the pathogenesis of atherosclerosis has not been fully explored;

- distinct cell targets of estrogen action - atherosclerotic lesion arises as a consequence of complex interplay between lipoproteins, inflammatory mediators, and various cell types (such as macrophages, endothelial cells, smooth muscle cells, B-cells, B-cells, dendritic cells, platelets, myofibroblasts, mast cells, etc.). It is conceivable that estrogens simultaneously exert both pro- and anti-atherogenic effects depending on their cellular target.

Examination of vascular lesions in animals represents an integral part of experimental approaches helping to study arteriosclerotic processes. With the advent of genetic engineering, transgenic mouse models have supplemented classical dietary cholesterol-induced disease models such as cholesterol-fed hamster, rabbit, pig, or monkey. In the last two decades, these transgenic models were widely used to specifically investigate the influence of estrogens on the development of atherosclerotic lesions. The present review summarizes the results of these studies and assesses their contribution toward better understanding of molecular mechanisms underlying anti- and/or pro-atherogenic effects of estrogens in humans.

\section{Effects of estrogens on atherosclerosis in animal models}

Atherosclerosis is often defined as a multifactorial disease. While selected pro- or anti-atherogenic processes can be effectively studied under in vitro conditions, the complex interplay between them can be explored only in appropriate animal models. Even though there is no one perfect animal model that completely replicates the stages of human atherosclerosis, cholesterol feeding is a common feature shared by most of them. Increased dietary cholesterol feeding produces a permanent hyperlipidemic state, which favors penetration of pro-atherogenic lipoproteins into the arterial wall and produces chronic inflammation accompanied by monocytosis promoting the recruitment of monocytes into the vessel wall. While a cholesterol-rich diet induces the development of atherosclerotic lesions in the disease-prone $\mathrm{C} 57 \mathrm{Bl} 6$ mouse strain, these are usually small and do not progress to resemble human lesions. However, mice deficient in apolipoprotein $\mathrm{E}$ (APOE) or LDL receptor (LDLR), which were generated on a $\mathrm{C} 57 \mathrm{Bl} 6$ background, are characterized by highly proatherogenic dyslipidemia with high LDL and low HDL levels in plasma and develop human-like lesions.

The effects of estrogens on diet-induced atherosclerosis have been studied in atherosclerosis-prone B6 mice as well as in Apoe $\mathrm{KO}$ and Ldlr $\mathrm{KO}$ mice under hypercholesterolemic conditions (Bourassa et al. 1996, Elhage et al. 1997a,b, 2001, Hodgin et al. 2001, 2002, Mayer et al. 2005, Tsuda et al. 2005, Seli et al. 2007, Villablanca et al. 2009). In female animals, the study design usually encompassed surgical or pharmacological castration followed by $\mathrm{E}_{2}$ substitution to assure $\mathrm{E}_{2}$ concentrations in plasma comparable to those seen in premenopausal women before ovulation (ca. 100 and $200 \mathrm{pg} / \mathrm{ml}$ ). Under such experimental conditions, ovariectomy exerted no effect or aggravated, while $\mathrm{E}_{2}$ substitution almost invariably ameliorated atherosclerosis. Additional studies documented that varying dose and timing of estrogen replacement critically affect the disease development. Elhage et al. (1997a) have shown that low-dose $\mathrm{E}_{2}$ fails to prevent fatty streak formation in Apoe knockout (KO) mice, while Freudenberger et al. (2010) reported even increased atherosclerosis in the same animal model treated with low $\mathrm{E}_{2}$ concentrations. Cann et al. (2008) found that $\mathrm{E}_{2}$ is ineffective in reducing atherosclerotic burden in Apoe $\mathrm{KO}$ mice, when administered 45 days after ovariectomy. The latter observation corroborates the results of interventional studies showing that women undergoing a period of low estrogen levels followed by reintroduction of estrogen treatment are more likely to experience a cardiovascular event than those on continuous treatment.

In addition to $\mathrm{E}_{2}$, natural $\mathrm{E}_{2}$ metabolites or phytoestrogens also exert anti-atherogenic effects in animal models. For instance, 2-methoxyestradiol (2-ME), which is the major metabolite of $\mathrm{E}_{2}$ formed via sequential conversion of $\mathrm{E}_{2}$ to 2-hydroxyestradiol and 2-ME by cytochrome $\mathrm{P} 450$ and catechol- $O$-methyltransferase (COMT) and is produced in various tissues in addition to ovary (Zacharia et al. 2004), was demonstrated to attenuate atherosclerosis in female Apoe $\mathrm{KO}$ mice (Bourghardt et al. 2007). Similar favorable effects were also seen after administration of isoflavones exerting weak estrogenic effects (Adams et al. 2002a,b).

Anti-atherogenic effects of estrogens in males were studied less intensely than those of females. Available results indicate, however, that estrogens reduce atherosclerotic burden in orchidectomized Apoe $\mathrm{KO}$ mice on cholesterol-rich diet or infused with angiotensin II (Ang-II) as well as in diabetic Apoe $\mathrm{KO}$ mice (Elhage et al. 1997a, Tse et al. 1999, Martin-McNulty et al. 2003). It ought to be emphasized that plasma $\mathrm{E}_{2}$ concentrations in treated male animals were comparable to those encountered in normal female animals. There is, however, compelling evidence suggesting that estrogens exert atheroprotective effects in males also under 
conditions in which $\mathrm{E}_{2}$ in plasma is not elevated to supraphysiological levels. For instance, anti-atherogenic effects exerted by dehydroepiandrosterone in oophorectomized rabbits or by testosterone in orchidectomized wild-type $\mathrm{B} 6$ mice or in testicular feminized mice exhibiting a nonfunctional androgen receptor were reduced by pharmacological inhibitors of aromatase an enzyme that converts testosterone to $\mathrm{E}_{2}$ (Hayashi et al. 2000, Nathan et al. 2001, Nettleship et al. 2007). More recently, reduction of atherosclerosis under testosterone treatment could be observed in orchidectomized Apoe $\mathrm{KO}$ mice lacking androgen receptor (Bourghardt et al. 2010). Collectively, these results indicate that estrogens exert atheroprotective effects in male animals acting locally within vasculature.

The biological effects of estrogens are mediated on a genomic level by ER $\alpha$ and ER $\beta$. The full-length ER $\alpha$ $(66 \mathrm{kDa})$ is composed of six domains termed A to $\mathrm{F}$ that harbor two transactivation functions AF1 and AF2 located in the domains $\mathrm{B}$ and $\mathrm{E}$ respectively. A truncated $\mathrm{ER} \alpha$ isoform (46 kDa) lacking the $\mathrm{N}$-terminal portion (domain $\mathrm{A} / \mathrm{B}$ ) has been identified in the uterus and endothelial cells. In addition, a $\mathrm{G}$ protein-coupled ER (GPR30) has been identified, which is localized in the endoplasmic reticulum and mediates nongenomic estrogen signaling (Maggiolini \& Picard 2010). The identity of ER involved in the protective effects against atherosclerosis is not entirely clear. Early studies suggested that the prevention of fatty streaks require the full-length $\mathrm{ER} \alpha$, as administration of $\mathrm{E}_{2}$ or isoflavones to ovariectomized ER $\mathrm{E} / \mathrm{Apoe}$ double $\mathrm{KO}$ mice only insignificantly reduced atherosclerotic lesion size (Hodgin et al. 2001, Adams et al. 2002a). Later investigations, however, documented that anti-atherogenic effects of $\mathrm{E}_{2}$ are preserved in female mice lacking full-length $\mathrm{ER} \alpha$ (Villablanca et al. 2009), which might be attributed to the presence of the $46 \mathrm{kDa} \mathrm{ER} \alpha$ isoform as well as the expression of the $55 \mathrm{kDa} \mathrm{ER} \alpha$ isoform arising as a consequence of a non-natural alternative splicing in these mice. Actually, $L d l r \mathrm{KO}$ mice engineered to specifically lack the AF1 transactivation function remained responsive to $\mathrm{E}_{2}$ treatment, while $\mathrm{E}_{2}$ protective effects were absent in animals lacking both the 66 and $46 \mathrm{kDa}$ isoforms (Billon-Galés et al. 2009a). Interestingly, these effects were also missing in mice lacking AF2 transactivation function, pointing to its crucial role in the estrogen-mediated atheroprotection at least in animal models of disease (Billon-Galés $e t$ al. 2011). In major contrast to female animals, deletion of $\mathrm{ER} \alpha$ in male B6 mice fed a high-cholesterol diet dramatically reduced atherosclerotic burden (Villablanca et al. 2004). As increased ER $\alpha$-mediated susceptibility to atherosclerosis was found in male mice lacking the $66 \mathrm{kDa}$ but maintaining the $46 \mathrm{kDa} \mathrm{ER} \alpha$ isoform, it cannot be excluded that the full-length
$\mathrm{ER} \alpha$ isoform may exert pro-atherogenic effects under certain experimental conditions.

While the preponderant majority of studies suggest that $\mathrm{ER} \alpha$ exerts protective effects in animal models of atherosclerosis, less information is available regarding the involvement of ER $\beta$ and GPR30. Unfortunately, the direct effect of $\mathrm{E}_{2}$ on the formation of early atherosclerotic lesions has not been studied in ERß KO mice on an Apoe-deficient or $L d l r$-deficient background. However, atheroprotective effects of isoflavones are persevered in ERß/Apoe double KO mice (Adams et al. $2002 a, b)$. On the other hand, the isoflavone estrogen genistein, which shows a 20-fold higher binding affinity to $\mathrm{ER} \beta$ than to $\mathrm{ER} \alpha$, inhibited atherosclerosis development in $L d l r \mathrm{KO}$ mice (Wang et al. 2008). In addition, 8 $\beta$-VE2 - a selective ER $\beta$ agonist - reduced atherosclerotic lesions in Apoe KO mice (Sun et al. 2011). The contribution of GPR30 to the pathogenesis of atherosclerosis has not as yet been evaluated. As already mentioned, the $\mathrm{E}_{2}$ metabolite, 2-ME, exerts atheroprotective effects, although it shows little affinity to classical ERs (Bourghardt et al. 2010).

\section{Mechanisms underlying anti-atherogenic effects of estrogens}

\section{Involvement of endothelial cells}

Endothelial monolayer separates blood, where lipoproteins and cellular participants (monocytes and lymphocytes) of atherosclerotic processes normally occur from the arterial wall. Consequently, the intact function of endothelial cells is critical for maintaining arterial integrity. Alterations of endothelial homeostatic mechanisms, which are known as endothelial dysfunction and precede the loss of endothelial integrity and denudation of the arterial wall, are initiated by several pro-atherogenic factors such as hypercholesterolemia or hyperhomocysteinemia and are encountered in pathological states favoring atherosclerosis such as hypertension or diabetes mellitus. Conversely, plasma-borne anti-atherogenic factors (HDLs and laminar blood flow) help to preserve integrity of the endothelial monolayer.

In vitro studies repeatedly demonstrated that $\mathrm{E}_{2}, \mathrm{E}_{2}$ metabolites, and synthetic estrogens exert favorable effects on endothelial function. One of the bestdescribed endothelial actions of $E_{2}$ is stimulation of nitric oxide $(\mathrm{NO})$ production, which depends on both genomic (expression of endothelial NO synthase (eNOS)) and nongenomic effects (activation of phosphatidylinositol 3-kinase and protein kinase AKT, phosphorylation of eNOS) (Arnal et al. 2010, Chow et al. 2010). Because the ability of $\mathrm{E}_{2}$ to promote an increase in eNOS activity and NO-dependent 
vasorelaxation are abolished in $\mathrm{ER} \alpha \mathrm{KO}$ mice and are emulated by highly selective ER $\alpha$ agonists, modulation of $\mathrm{NO}$ production by $\mathrm{E}_{2}$ is likely mediated by $\mathrm{ER} \alpha$ (Arnal et al. 2010, Bolego et al. 2010). However, treatment of endothelial cells with $\mathrm{E}_{2}$ also stimulates covalent adduction of a nitrosyl group to cysteins (S-nitrosylation), which represents a key route for NO to directly modulate protein functions and which depends on ER $\beta$ (Zhang et al. 2010, 2012). In addition, 2-ME, which shows affinity neither to ER $\alpha$ nor to ER $\beta$, abrogates vascular constriction by increasing the expression and the redistribution of eNOS and by promoting local NO production (Dubey \& Jackson 2009, Fenoy et al. 2010). Another vasorelaxing substance liberated from endothelial cells under the influence of $\mathrm{E}_{2}$ is prostacyclin ( $\mathrm{PGI}_{2}$; Mikkola et al. 1995, 1996, Seeger et al. 1999, Sherman et al. 2002). The latter effect depends on the combined increased synthesis of cyclooxygenase 1 and/or 2 (COX1 (PTGS1) and COX2 (PTGS2)) and prostaglandin synthase $\left(\mathrm{PGH}_{2}\right)$, which ultimately leads to a shift from COX-dependent vasoconstriction to vasodilation (Jun et al. 1998, Akarasereenont et al. 2000, Kawagoe et al. 2007, Sobrino et al. 2009, 2010, Su et al. 2009). Experiments with ER agonists and endothelial cells transfected with COX promoter suggest the involvement of both $\mathrm{ER} \alpha$ and $\mathrm{ER} \beta$ in $\mathrm{E}_{2}$-dependent $\mathrm{PGI}_{2}$ production (Gibson et al. 2005, Su et al. 2009, Sobrino et al. 2010), albeit 2-ME was also demonstrated to enhance $\mathrm{PGI}_{2}$ liberation (Barchiesi et al. 2006). In addition to the release of vasorelaxants, estrogens also prevent the activation of endothelium, which constitutes an essential component of endothelial dysfunction. Both $\mathrm{E}_{2}$ and its metabolites such as estron and 17 -epiestriol, as well as $5 \alpha$-androstane- $3 \alpha, 17 \beta$-diol-( $3 \alpha-$

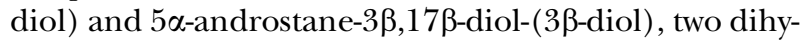
drotestosterone metabolites that are unable to bind the androgen receptor but exhibit affinity for ERs, blunt the cell-surface expression of vascular cell adhesion molecule-1 (VCAM1), intercellular cell adhesion molecule (ICAM-1), E-selectin, P-selectin, as well as CD40 and CD40L in endothelial cell exposed to proatherogenic factors such as TNF $\alpha$, IL1B, lipopolysaccharide (LPS), IFN $\gamma$ or lysophosphatidylcholine (LPC; Nathan et al. 1999, Simoncini et al. 1999, 2000, Mukherjee et al. 2002, 2003, Mori et al. 2004, Geraldes et al. 2006, Ling et al. 2006, Wang et al. 2008, Norata et al. 2010, Thor et al. 2010, Rauschemberger et al. 2011). At the same time, $\mathrm{E}_{2}$ reduces the monocyte expression of $\alpha_{4} \beta_{1}$ and $\alpha_{L} \beta_{2}$ integrins, binding partners for VCAM1 and ICAM-1, respectively, in a process involving downregulation of RAC1 activity (Friedrich et al. 2006). As a consequence, estrogens reduce both the monocyte and neutrophil adhesion to the endothelial monolayer and the transendothelial migration of monocytes under in vitro conditions (Alvarez et al. 2002,
Geraldes et al. 2006). In addition, exposure of endothelial cells to estrogens suppresses the NADPH oxidase activity and thereby the intracellular production of reactive oxygen species (ROS), which is instrumental for the expression of adhesion molecules in response to pro-atherogenic factors (Wagner et al. 2001). Experiments using ER agonists and antagonists point to both $E R \alpha$ and $E R \beta$ as mediators of suppressing effects of $E_{2}$ on endothelial activation (Mukherjee $e t$ al. 2003, Mori et al. 2004, Geraldes et al. 2006), though again these effects could also be observed in the presence of 2-ME (Kurokawa et al. 2007, Dubey \& Jackson 2009).

In addition to beneficial effects on endothelial function, estrogens promote endothelial integrity. $\mathrm{E}_{2}$, 2-ME, and isoflavones enhance endothelial barrier function and reduce its permeability to pro-atherogenic factors such as native and oxidized LDLs (Carbajal \& Schaeffer 1998, Delarue et al. 1998, Fujimoto et al. 1998, Gardner et al. 1999, Chi et al. 2004, Liu et al. 2005, Sumanasekera et al. 2007, Dubey \& Jackson 2009). The latter effect depends on the modulation of tight junction proteins such as occludin and/or claudin and is mediated via both $\mathrm{ER} \alpha$ and $\operatorname{ER} \beta$ (Ye et al. 2003, Burek et al. 2010, Sandoval \& Witt 2011). Furthermore, estrogens promote endothelial cell proliferation and survival. Several studies documented mitogenic effects of $\mathrm{E}_{2}$ either acting alone or in combination with serumderived growth factors in endothelial cell cultures (Geraldes et al. 2002, Sengupta et al. 2004, Williams et al. 2004, Kawagoe et al. 2007, Oviedo et al. 2011). Moreover, endothelial apoptosis initiated by $\mathrm{TNF} \alpha$, $\mathrm{H}_{2} \mathrm{O}_{2}$, or oxidized LDL was consistently inhibited in the presence of estrogens in a process involving activation of protein kinases MAPK and AKT, increased expression of anti-apoptotic proteins BCL2 and BCLXL (BCL2L1), and disabling of the pro-apoptotic protein BAD (Alvarez et al. 1997, Spyridopoulos et al. 1997, Liu et al. 2002, Lu et al. 2006, Florian \& Magder 2008, Yu et al. 2009). In addition, acting through ER $\alpha$, estrogens were demonstrated to prevent mitochondrial ROS production in endothelial cells as well as ROSinduced apoptosis by interfering with cytochrome $c$ release from mitochondria (Sudoh et al. 2001, Razmara et al. 2008). Finally, $\mathrm{E}_{2}$ was found to promote formation of the eNOS-ER $\alpha$ complex that interacts with telomerase catalytic subunit (hTERT) gene promoter, enhances hTERT transcription, and thereby increases activity of telomerase, which plays pivotal role in the determination of the cell lifespan and countervails cellular senescence (Hayashi et al. 2006, Grasselli et al. 2008).

Several putatively protective effects of estrogens observed in endothelial cells under in vitro conditions could be recapitulated in animal models in the context of atherosclerotic disease. For instance, $\mathrm{E}_{2}$ was found to countervail detrimental effects of hypercholesterolemia on arterial vasorelaxation by augmenting COX2 
expression and induction, and production of $\mathrm{PGI}_{2}$ by estrogens was postulated to play an important role in the prevention of fatty streak formation (Ghanam $e t$ al. 2000, Egan et al. 2004). Somewhat unexpectedly, increasing $\mathrm{NO}$ bioavailability in ovariectomized Apoe $\mathrm{KO}$ mice failed to affect development of fatty streaks, suggesting that prevention of early atherosclerosis by $\mathrm{E}_{2}$ is independent of NO production (Elhage et al. 1997b, Hodgin et al. 2002). However, chronic induction of endothelial dysfunction by prolonged administration of NOS inhibitor aggravated atherosclerosis and specifically abolished atheroprotective effects of $\mathrm{E}_{2}$ in intact but not in de-endothelialized aorta in female rabbits on a hypercholesterolemic diet (Holm et al. 1997). In addition, a close inverse correlation between NO production and the arterial lesion extent was observed in rabbits under the condition of severe hypercholesterolemia combined with or without endothelial dysfunction (Nascimento et al. 1999, Hayashi et al. 2000). In a similar rabbit model of atherosclerosis, hypercholesterolemia-induced monocyte adhesion and penetration into the subendothelial area were more pronounced in male than in female rabbits (Nathan et al. 1999). Both monocyte adhesion and VCAM1 expression were aggravated by oophorectomy and these were reversed after treatment of female animals with $\mathrm{E}_{2}$. Later studies performed on hypercholesterolemic Apoe-deficient animals confirmed the pivotal role of endothelial VCAM1 expression for the atheroprotective effects of estrogens (Gourdy et al. 2003, Martin-McNulty et al. 2003).

The central role of endothelium for the atheroprotective effects of estrogens was initially suggested by Holm et al. (1997), who demonstrated complete loss of anti-atherogenic effects of estrogens in hypercholesterolemic rabbits after destructing the endothelial layer in the aorta using a balloon catheter. However, the ultimate proof for the obligatory involvement of endothelial cells in the estrogen-exerted atheroprotection in animal models was provided by Billon-Galés et al. (2009a). Using an approach utilizing CreLox strategy (with Cre recombinase under control of the endothelial-specific Tie promoter), these authors have clearly shown that elimination of $\mathrm{ER} \alpha$ in endothelial cells fully abolishes the atheroprotective action of $\mathrm{E}_{2}$ in ovariectomized $L d l$ r-deficient mice and this was accompanied by a complete abrogation of the $\mathrm{E}_{2}$-induced $\mathrm{NO}$ release. These results not only define the endothelial monolayer as a key target of estrogens in the vasculature but also pinpoint $\mathrm{ER} \alpha$ as a principal mediator of estrogen action. In this regard, they fully corroborate with previous findings that $\mathrm{ER} \alpha$ is necessary and sufficient for $\mathrm{E}_{2}$-induced $\mathrm{NO}$ and $\mathrm{PGI}_{2}$ production and that it likely mediates the suppressive effects of $\mathrm{E}_{2}$ on VCAM1 expression in endothelial cells (Javeshghani et al. 2006, 2007).

\section{Involvement of macrophages, dendritic cells, and lymphocytes}

Macrophages and lymphocytes are intimately involved in the pathogenesis of atherosclerosis. Monocytes are recruited to the arterial wall, where they (after conversion to macrophages) initiate a processes culminating in fully fledged intra-arterial inflammation. The contribution of macrophages to this process is manifold (see Ley et al. (2011) and Moore \& Tabas (2011) for the most recent reviews) and encompasses

- uncontrolled ingestion of oxidatively modified LDLs and formation of cholesterol-loaded foam cells. HDL, a potent anti-atherogenic factor in humans, acts as a cholesterol acceptor and counterbalances cholesterol accumulation in macrophages in a process dubbed cholesterol efflux;

- production of pro-inflammatory cytokines and chemokines, such as IL1B and TNF $\alpha$, that activate endothelial and smooth muscle cells and promote further recruitment of mononuclear cells. In addition, IL1B, IL12 (IL12A), and IL18 activate T-cells and facilitate the adaptive immune response;

- antigen presentation via MHC-II, which further contributes to the activation of T-cells. This mechanism is also thought to account for the proatherogenic effects of dendritic cells, which are present in atherosclerotic lesions.

The number of macrophages recruited into the arterial wall is controlled by mutually opposed processes of proliferation and apoptosis. Macrophage colonystimulating factor (M-CSF) - a cytokine promoting monocyte-macrophage transition and macrophage growth - increases macrophage numbers in plaques, while its partial absence protects against the development of atherosclerotic lesions. Conversely, suppression of macrophage apoptosis was found to increase macrophage number in plaques and to enhance plaque formation in atherosclerosis-prone mice. In advanced atherosclerotic lesions, however, apoptotic macrophages become secondarily necrotic and coalesce over time into a key feature of vulnerable plaques - the necrotic core. This event is critically important, as necrotic core formation is thought to promote plaque disruption and ultimately acute atherothrombotic vascular disease.

Despite the key relevance of cholesterol accumulation in macrophages for the formation of atherosclerotic lesions, little effort has been devoted toward better understanding of the influence of estrogens on macrophage cholesterol homeostasis. Currently available information suggests that estrogens favor discharging of cellular cholesterol and reduce the cholesterol burden of atherosclerotic plaques. Actually, exposure of human or murine macrophages to $\mathrm{E}_{2}$ decreased 
their cholesterol ester content by stimulation of neutral cholesterol ester hydrolase and inhibition of acylCoAcholesterol transferase (Cheng et al. 1999, Napolitano et al. 2001, 2002, Wilson et al. 2008, Corcoran et al. 2011). In addition, $\mathrm{E}_{2}$ was reported to reduce macrophage uptake of modified LDLs such as acetylated, oxidized, or aggregated LDL, and this latter effect was found to specifically depend on the ER $\alpha$-mediated suppression of the expression of scavenger receptor CD36 (Sulistiyani \& St Clair 1997, McCrohon et al. 1999, Allred et al. 2006, Wilson et al. 2008). More recently, ER $\alpha$-deficient macrophages were shown to express reduced amounts of proteins involved in cholesterol efflux such as ABCA1 and APOE and to export less cholesterol when incubated with $\mathrm{HDL}$, whereas $\mathrm{E}_{2}$ associated with $\mathrm{HDL}$ particles was found to potentiate HDL-induced cholesterol efflux mediated by scavenger receptor class B type I (SR-BI (SCARB1)) (Badeau et al. 2009, Ribas et al. 2011). Several studies documented that HDL carries $\mathrm{E}_{2}$ in the form of fatty acyl esters produced in a reaction catalyzed by lecithin-cholesterol acyltransferase (LCAT; Helisten et al. 2001, Höckerstedt et al. 2002, 2004). HDL-derived $\mathrm{E}_{2}$ esters are internalized via LDLR- and/or SR-BImediated mechanisms and subsequently hydrolyzed intracellularly to unfold their effects (Badeau et al. $2007 a, 2009)$. In addition, $\mathrm{E}_{2}$ esters are transferred by cholesterol ester transfer protein to LDL particles, where they reduce oxidation by free radicals produced in copious amounts by activated macrophages (Helisten et al. 2001, Höckerstedt et al. 2002). Overall, these results suggest that estrogens not only favorably affect cholesterol homeostasis and reduce macrophage cholesterol burden but also protect LDL particles against oxidation, thereby further limiting LDL retention and cholesterol accumulation in the arterial wall.

Additional atheroprotective effects exerted by estrogens in macrophages may be related to modulation of growth and apoptotic processes. While evidence for the direct regulation of macrophage proliferation by estrogens is lacking, these hormones were shown to modulate bone marrow M-CSF production and reduced aortic expression of M-CSF was found in Apoe-deficient mice treated with $\mathrm{E}_{2}$ (Sarma et al. 1998, Lea et al. 1999, Martin-McNulty et al. 2003). $\mathrm{E}_{2}$ was also demonstrated to promote apoptosis of monocytes, monocyte-derived macrophages, and macrophage-derived osteoclasts, and these effects were largely attributed to the upregulation of Fas and Fas ligand (FasL (FASLG)) as well as the activity of caspases 8 and 3 (Carruba $e t$ al. 2003, Mor et al. 2003, Thongngarm et al. 2003, Saintier et al. 2006, Nakamura et al. 2007, Montagna et al. 2009). In this context, it is worth noting that Fas/FasL effectively regulate apoptosis of cholesterol-loaded macrophages and that Fas and FasL-mediated macrophage apoptosis coincides with decreased lesion cellularity and regression of atherosclerosis in mice
(Esaki et al. 2000, Yao \& Tabas 2000). Hence, it would be tempting to speculate that estrogens countervail the early lesion development by reducing the number of intimal macrophages. However, in one instance, $\mathrm{E}_{2}$ has also been demonstrated to inhibit macrophage apoptosis in a process dependent on the cytoplasmic ER $\alpha$ receptor and mediated by the increased expression of anti-apoptotic molecule BCL2 (Subramanian \& Shaha 2009). This latter process might be interpreted as favorable in the late lesion scenario, where the prevention of macrophage apoptosis attenuates necrotic core formation.

With respect to macrophage and dendritic cell functions related to initiation, propagation, and/or resolution of inflammation, investigations on the impact of estrogens led to equivocal results. Both $\mathrm{E}_{2}$, phytoestrogens, and ER agonists were reported to attenuate pro-inflammatory activation induced by tolllike receptor (TLR) agonists such as LPS or by receptor activator of nuclear factor- $\kappa \mathrm{B}$ ligand in primary human and murine macrophages, in monocyte-derived macrophage lines (RAW247.6, J774, and THP-1), as well as in primary microglia and in microglial cell lines (Frazier-Jessen \& Kovacs 1995, Deshpande et al. 1997, Bruce-Keller et al. 2000, Vegeto et al. 2004, Bellosta et al. 2007, Hämäläinen et al. 2007, Yoshitake et al. 2008, Yuan et al. 2008, Lee et al. 2008, Rettew et al. 2010). This has been inferred from reduced expression of iNOS, decreased production of pro-inflammatory cytokines and chemokines (TNF $\alpha$, IL6, IL12, MCP1 (CCL2), MIP-1 $\alpha$ (CCL3)), and the decreased production and release of the matrix metalloproteinase 9. In addition, $\mathrm{E}_{2}$ was reported to inhibit MHC-II expression in macrophages exposed to INF $\gamma$ (Adamski et al. 2004). While no single mechanism underlying these effects could be identified, estrogens were found to interfere with several intracellular pro-inflammatory signaling pathways including phosphorylation, nuclear translocation, and DNA binding of the transcription factor NF$\kappa \mathrm{B}$ as well as phosphorylation and activation of signal transducers and activators of transcription (STAT) 1 and 3 (Deshpande et al. 1997, García Palacios et al. 2005, Ghisletti et al. 2005, Chen et al. 2006, Hämäläinen et al. 2007, Lee et al. 2008, Yoshitake et al. 2008, Xiu-li et al. 2009). In particular, inhibitory effects of $E_{2}$ on NF-кB activation were uniformly found in several macrophage cell systems and were attributed to both genomic (regulation of let-7a and miR-125b micro-RNAs) and nongenomic (regulation of protein kinases MAPK and AKT) action (Ghisletti et al. 2005, Murphy et al. 2010). Moreover, the reduced iNOS expression, TNF $\alpha$ production, and NF- $\kappa \mathrm{B}$ activation seen in the presence of $\mathrm{E}_{2}$ were partially abolished in macrophages lacking peroxisome proliferation-activating receptor $\alpha$ (PPAR $\alpha$; Crisafulli et al. 2009). The latter observation, which suggests that $\operatorname{PPAR} \alpha$ contributes to the 
anti-inflammatory activity of $\mathrm{E}_{2}$, is of particular relevance to the pathogenesis of atherosclerosis, as $\operatorname{PPAR} \alpha$ is a molecular target of fibrates - drugs with established anti-atherogenic and anti-inflammatory properties.

The anti-inflammatory effects of estrogens on macrophages have been confirmed in several animal models of inflammation. For instance, $\mathrm{E}_{2}$ treatment blocked $\mathrm{NF}-\mathrm{\kappa B}$ translocation and prevented glial reactivity in rats undergoing chronic spinal cord injury (Sribnick et al. 2010). Similarly, both $\mathrm{E}_{2}$ and synthetic ER agonists normalized NF- $\kappa \mathrm{B}$ activation and pro-inflammatory cytokine production as well as reduced TLR4 expression in Kupfer cells following trauma-hemorrhage in rats and mice, and these effects were shown to be specifically mediated by ER $\alpha$ (Hsieh et al. 2007, Suzuki et al. 2007, 2008). In addition, transplant arteriosclerosis in rats or rabbits as well as macrophage infiltration into the allograft intima were potently reduced in $\mathrm{E}_{2}$-treated recipients, and this was associated with almost complete suppression of MHC-II antigen expression in transplanted arteries (Lou et al. 1996, Saito et al. 1998). Most recently, ER $\alpha$-deficient macrophages were found refractory to IL4-induced activation of anti-inflammatory phenotype in vitro and presented with elevated expression of chemokines and markers of immune cell activity, when isolated from animals with myeloid-specific ER $\alpha$ deficiency (Ribas et al. 2011). Importantly, Ldlr $\mathrm{KO}$ animals lacking $\mathrm{ER} \alpha$ in myeloid cells showed twofold increase in atherosclerotic lesion area. In the most striking contrast to these findings, Rettew et al. (2009) observed pro-inflammatory effects of estrogens in a murine model of sepsis. In this model, removal of endogenous estrogens by means of ovariectomy decreased production of pro-inflammatory cytokines and concomitantly reduced cell surface expression of TLR4 on macrophages. Conversely, $\mathrm{E}_{2}$ replacement significantly elevated macrophage $T L R 4$ expression, and this effect was accompanied by significantly higher inflammatory cytokine levels after in vivo LPS challenge. Potentiating effects of $\mathrm{E}_{2}$ on macrophage activation were also observed by Calippe et al. (2008), who found that administration of $\mathrm{E}_{2}$ to ovariectomized mice markedly increased the expression of IL1B, IL6, IL12p40, and iNOS by peritoneal macrophages in response to LPS ex vivo. Moreover, $\mathrm{E}_{2}$ treatment of animals resulted in the inhibition of phosphoinositide kinase-3 (PI3K) activity and AKT phosphorylation in LPS-activated macrophages, whereas NF- $\mathrm{B}$ p65 transcriptional activity was concomitantly increased. Further studies showed that targeted disruption of $E R \alpha$ gene in macrophages totally abolished the effect of $\mathrm{E}_{2}$ on the expression of inflammatory mediators by peritoneal macrophages, thus indicating that $\mathrm{E}_{2}$ directly targeted these cells to exert pro-inflammatory effects (Calippe et al. 2010). The same group noticed that ER $\alpha$-mediated signaling is required for optimal dendritic cell function as assessed by MHC-II and CD86 expression and pro-inflammatory cytokine production (IL6 and IL12) and that estrogens enhance susceptibility to experimental myasthenia gravis by augmenting dendritic cell activation and proinflammatory Th1 response (Delpy et al. 2005, Douin-Echinard et al. 2008). The pivotal role of estrogens in regulating dendritic cell differentiation and activation was also highlighted in other studies, in which $\mathrm{E}_{2}$ was shown to support GM-CSF-initiated transition of bone marrow progenitor cells into dendritic cells, to prevent apoptosis, and to augment the production of proinflammatory and pro-atherogenic cytokines IL12 and IFN $\gamma$ by dendritic cells in response to TLR4 or TLR7 agonists (Carreras et al. 2008, 2010, Kawasaki et al. 2008, Siracusa et al. 2008, Li et al. 2009). The reasons why estrogens differentially affect macrophage and dendritic cell activation in vitro and in vivo and thereby exert dual effects on inflammation are currently unclear (see Straub (2007) for exhaustive discussion). It may be speculated that the duration of treatment plays a role in this respect. Actually, shortterm cell or animal treatment was used in most in vitro and in vivo experiments, in which suppressing effects of estrogens on macrophage activation were studied, while prolonged administration (over 35-60 days) was applied in experiments performed by Calippe et al. or Rettew et al.

In yet another twist in the estrogens and atherosclerosis story, Rayner et al. (2008) showed that estrogens dose-dependently promote the release of heat-shock protein 27 (HSP27 (HSPB1)) from macrophages. The latter protein binds to scavenger receptor A (SR-A) and thereby inhibits ingestion of cholesterolrich lipoproteins and formation of foam cells. In addition, HSP27 promotes anti-inflammatory macrophage response characterized by decreased and elevated productions of IL1B and IL10 respectively. Studies in vivo documented reduced atherosclerosis in HSP27-overesxpressing female but not in male mice and additionally revealed the inverse relationship between plasma HSP27 and $\mathrm{E}_{2}$ concentrations. Further investigations demonstrated that $\mathrm{E}_{2}$ treatment is more effective in preventing atherosclerotic lesion formation in ovariectomized HSP27-overesxpressing mice than wild-type mice (Rayner et al. 2009). Most strikingly, the atheroprotective effects of $\mathrm{E}_{2}$ in HSP27-overexpressing mice were mimicked by selective ER $\beta$ agonist but not by ER $\alpha$-specific agonist. Taken together, these results reveal an entirely new mechanism, by which estrogens may protect against the development of atherosclerosis and emphasize a previously overseen role of ER $\beta$ as potential therapeutic target in vascular atherosclerotic diseases (Fig. 1). 


\section{Involvement of smooth muscle cells}

Vascular smooth muscle cells (VSMC) represent a third cell type in addition to endothelial cells and macrophages that determine atherosclerotic plaque development (Doran et al. 2008, Orr et al. 2010). After intimal injury, endothelial cells, platelets, and macrophages release mediators, such as growth factors and cytokines, that promote VSMC phenotype change from the quiescent 'contractile' to the active 'synthetic' and induce their proliferation and migration from the media to the intima. Like macrophages, VSMC can express a variety of receptors for lipid uptake and can form foam-like cells, thereby participating in the early accumulation of plaque lipid. In addition, activated VSMC secrete pro-inflammatory cytokines and chemokines and release free radicals that modify lipoproteins. Like endothelial cells, VSMC express adhesion molecules to which monocytes and lymphocytes can adhere and migrate into the vessel wall. Hence, VSMC essentially contribute to development of early atherosclerotic plaques. However, VSMC are also the major source of the extracellular matrix and at later stages of atherosclerosis provide a substantial input to plaque stability (Clarke \& Bennett 2006).

Studies on interactions between estrogens and VSMC clearly point to the profound influence of $\mathrm{E}_{2}$ and synthetic estrogens on VSMC function. Inhibitory effects of $\mathrm{E}_{2}$ on VSMC proliferation induced by serum or serum-derived pro-atherogenic factors such as fibroblast growth factor, PDGF, Ang-II, or LPS were shown in the overwhelming majority of in vitro studies and were also accompanied by the $\mathrm{G}_{1}$ arrest, reduced expression of cell cycle regulatory proteins including cyclin $\mathrm{D}$, attenuated phosphorylation of retinoblastoma $(\mathrm{Rb})$ protein, as well as reduced activation of mitogenactivated kinases such as ERK1/2 (MAPK3/6) and

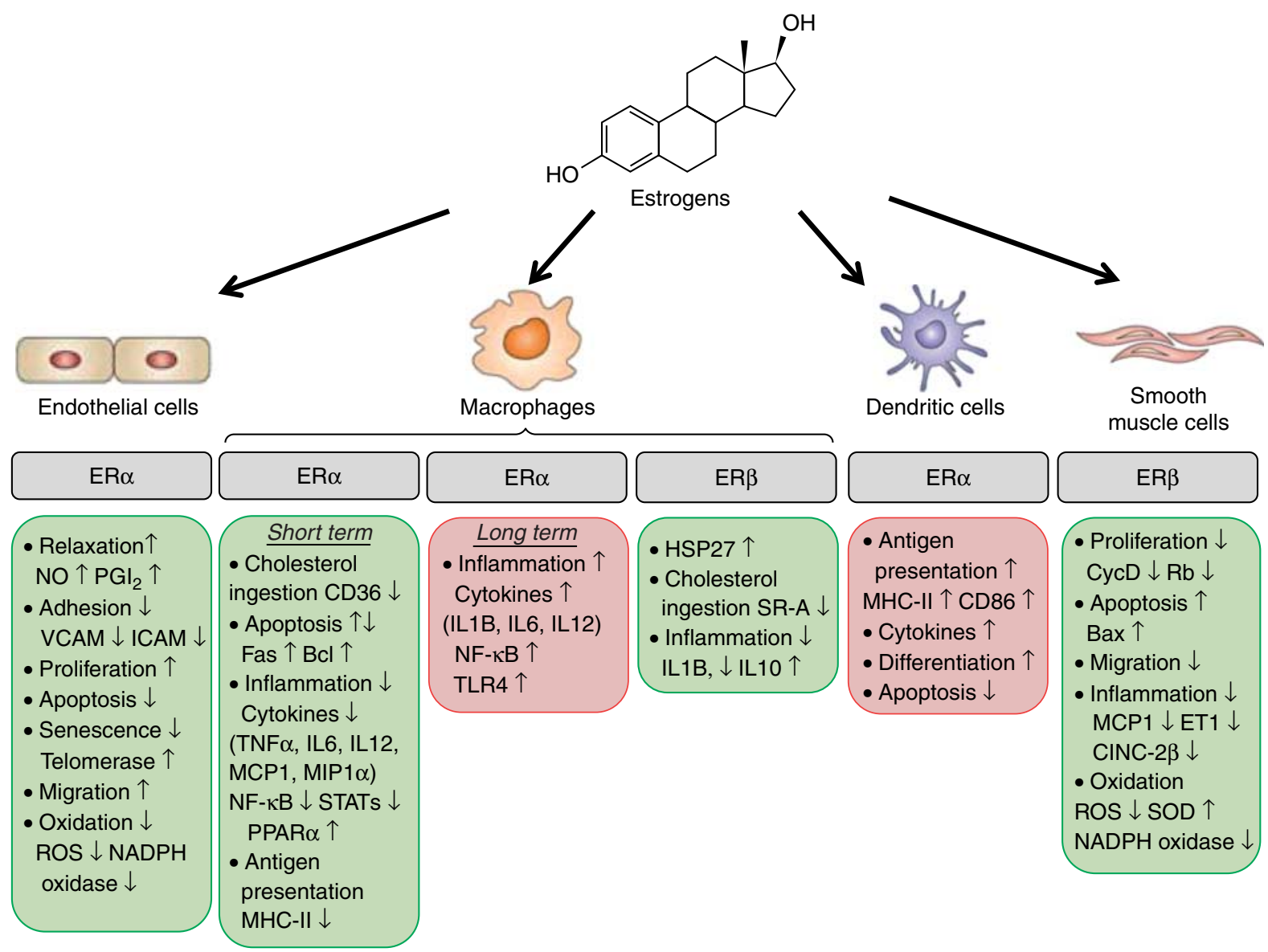

Figure 1 Molecular modes of estrogen action in atherosclerotic disease. Green and red boxes indicate pro- and anti-atherogenic effects respectively. CINC, cytokine-induced neutrophil chemoattractant; CycD, cyclin D; ER, estrogen receptor; ET, endothelin; HSP, heat-shock protein; ICAM, intercellular cell adhesion molecule; IL, interleukin; MCP, monocyte chemoattractant protein;

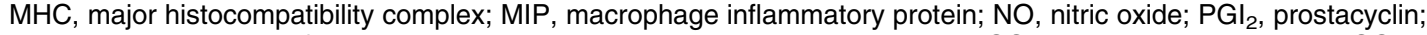
PPAR, peroxisome proliferator-activated receptor; $\mathrm{Rb}$, retinoblastoma protein; ROS, reactive oxygen species; SOD, superoxide dismutase; SR-A, scavenger receptor type A; STAT, signal transducer and activator of transcription; TNF, tumor necrosis factor; TLR, toll-like receptor; VCAM, vascular cell adhesion molecule. 
MEK1/2 (MAP2K1/2) (Dai-Do et al. 1996, Espinosa et al. 1996, Suzuki et al. 1996, Kappert et al. 2006, Wang et al. 2007). In parallel, $\mathrm{E}_{2}$ tended to promote VSMC apoptosis by activating p42/44 and/or p38 MAPK and upregulating the pro-apoptotic protein BAX (Mori-Abe et al. 2003, Yang et al. 2007, Ding et al. 2009). $\mathrm{E}_{2}$ was also shown to inhibit VSMC migration toward pro-atherogenic chemoattractants such as PDGF or Ang-II, and this was likely dependent on the inhibition of the small G protein RAC1 (Dai-Do et al. 1996, Kolodgie et al. 1996, Yoon et al. 2001, Hwang et al. 2002, Ling et al. 2002, Takahashi et al. 2003, Kappert et al. 2006). In addition, estrogens were demonstrated to reduce inflammatory activation of VSMC. For instance, the expression of $C O X 2$, MCP1, and endothelin 1 (ET1 (EDN1)) in response to serum, LPS, or Ang-II, respectively, was markedly attenuated in VSMC exposed to $\mathrm{E}_{2}$ (Seli et al. 2001, Hong et al. 2004, Kawagoe et al. 2007, Jiang et al. 2010). Xing et al. (2007) found that $\mathrm{E}_{2}$ inhibits $\mathrm{TNF} \alpha$-stimulated expression of the neutrophil-specific chemokine cytokine-induced neutrophil chemoattractant (CINC)-2 $\beta$ and suggested that this effect might be responsible for the reduced infiltration of neutrophils, which is observed in animal models after vessel injury. Finally, estrogens are also known to reduce oxidative stress in VSMC by increasing expression of antioxidative enzymes such as superoxide dismutase and reducing expression and/or activity of NADPH oxidase (Strehlow et al. 2003, Wassmann et al. 2005, Wing et al. 2009, Broughton et al. 2010, Sivritas et al. 2011). The antiproliferatory, pro-apoptotic, anti-migratory, anti-oxidative, and anti-inflammatory in vitro effects of estrogens collectively translate into reduced neointima formation under in vivo conditions. The latter effect has been repeatedly observed in ligation-injured carotid arteries of $\mathrm{E}_{2}$-treated ovariectomized mice as well as in ballooninjured rabbit aortas or rat carotid arteries.

$E R \beta$ is a predominant mRNA transcript in VSMC (Register \& Adams 1998). However, the identity of ER mediating the anti-atherogenic effects of estrogens in VSMC remains enigmatic. For instance, the proapoptotic effect of $\mathrm{E}_{2}$ could be observed in the A10 VSMC line only after overexpressing $E R \alpha$ in these cells (Mori-Abe et al. 2003). Furthermore, stimulatory effects exerted by $\mathrm{E}_{2}$ on the superoxide dismutase expression seem to depend on ER $\alpha$ (Sivritas et al. 2011). By contrast, treatment of porcine VSMC with antisense oligonuclotides complementary to ERß mRNA abrogated the inhibitory effects of $\mathrm{E}_{2}$ on ERK1/2 activity and proliferation (Geraldes et al. 2003). Likewise, the inhibitory effects exerted by estrogens on AngII-induced VSMC proliferation and TNF $\alpha$-stimulated CINC-2 $\beta$ expression were prevented by ER $\beta$ but not by ER $\alpha$ receptor inhibitors (Xing et al. 2007). ERß mRNA was found to be markedly expressed after balloon injury in rats, and local delivery of selective ER $\beta$ agonists was shown to more effectively reduce neointima formation than ER $\alpha$ agonists (Lindner et al. 1998, Aavik et al. 2001, Krom et al. 2007). Collectively, these results point to ER $\beta$ as a major mediator of estrogen action in VSMC. More recently, GPR30 was found to be expressed on VSMC and to modulate vascular tone in rats and in isolated human arteries (Haas et al. 2009). GPR30 activation was shown to inhibit VSMC proliferation and NADPH oxidase activation, and GPR30 expression was required for the estrogen-mediated VSMC apoptosis (Ding et al. 2009, Haas et al. 2009, Broughton et al. 2010). Hence, GPR30 activation in VSMC may be tentatively added to the list of cellular effects exerted by estrogens, which are considered atheroprotective. Finally, 2-ME, an estrogen metabolite with no affinity to classical ERs, was shown to prevent injury-induced neointima formation in rats (Barchiesi et al. 2006). Several studies in vitro documented that 2-ME inhibits VSMC proliferation at both $\mathrm{G}_{0} / \mathrm{G}_{1}$ and $\mathrm{G}_{2} / \mathrm{M}$ cell cycle phase and downregulates cyclones D and $\mathrm{B}$, while upregulating p27 - a negative regulator of VSMC growth, and that these effects are missing in VSMC lacking COMT that do not effectively convert $\mathrm{E}_{2}$ to 2-ME (Zacharia et al. 2003, Barchiesi et al. 2006, Dubey \& Jackson 2009). Collectively, these results suggest that at least part of the atheroprotective effects related to the effects of estrogens on VSMC are mediated in a fashion independent of classical ERs.

\section{Conclusions and directions for future research}

Estrogen-dependent regulation of vascular gene expression and vascular physiology encompasses complex processes involving both nuclear and membrane-associated ER signaling pathways. Recent years have witnessed major progress in understanding how these regulatory processes contribute to the atheroprotective effects exerted by naturally occurring estrogens and synthetic ER agonists. Studies on animal models of atherosclerosis provided compelling evidence that physiological estrogen levels potently attenuate both early and advanced stages of atherosclerosis lesion development in females and suggested similar protective effects in males. Using tissue-specific KO and/or highly selective ER agonists, these studies clearly defined endothelial cells as a primary target of the anti-atherogenic action of estrogens, demonstrated that non-nuclear ER $\alpha$ signaling plays a crucial role in this respect, and allowed dissecting the effects on cardiovascular endpoints from uterotrophic response (Arnal et al. 2010, Bolego et al. 2010). It could also be established that ER $\beta$ signaling contributes to atheroprotective effects exerted by estrogens and this has been attributed primarily to the modulatory effects on smooth muscle and probably also on macrophage 
function. New insights into molecular mechanisms underlying vascular effects of estrogens improved our capacity to correctly interpret surprising and sometimes contradictory data from large interventional studies, in which hormone-replacement therapy failed to reduce cardiovascular risk despite favorable effects on plasma lipid profile and several other coronary risk factors. For instance, results of animal studies demonstrating that estrogens may exert both pro- and anti-atherogenic effects depending on the disease stage provide experimental support to the increasingly accepted 'timing hypothesis' according to which continuous treatment with estrogens may result in different outcomes than reinstatement of therapy several years after menopause. By the same token, dual pro- or anti-inflammatory effects of estrogens, which seem to depend on the duration of treatment, corroborate well with the results of clinical studies demonstrating protective effects of short-term ( $<10$ years) menopausal hormone therapy and gradual disappearance of protection in succeeding years (Rossouw et al. 2007). Finally, it seems possible that some mechanisms instrumental to presumed atheroprotection exerted by estrogens may be less effective in women after menopause. For instance, BH4 - an obligatory cofactor for eNOS - is reduced with aging and its absence may at least partially prevent estrogens to exert atheroprotective effects via the endothelium. Similar effects antagonizing the beneficial action of estrogens on endothelial cells may be exerted by 27-hydroxycholesterol, which binds to and blocks ER $\alpha$ and increased concentrations of which are observed in postmenopausal women (Umetani \& Shaul 2011). It also cannot be excluded that estrogens are less effective in postmenopausal women due to increased esterification by LCAT and estrogen ester sequestration in adipose tissue (Badeau et al. 2007b).

Despite the immense progress in understanding the role of estrogens in atherosclerosis, a number of questions regarding mechanisms underlying their protective effects remain unanswered. We still need to know whether various estrogen concentrations, which physiologically vary over two orders of magnitude, exert distinct signaling effects (either pro- or anti-atherogenic) in diverse cells involved in the pathogenesis of atherosclerosis. We also need to know to what extent and how the cessation of endogenous estrogen production affects ER expression and function in the vasculature and thereby enhances or attenuates their pro- or anti-atherogenic effects. Finally, the potential pro- or anti-atherosclerotic effects of newly identified ERs such as GPR30 have not been addressed in animal models of disease. Clearly, further experimental work including development of new animal models better reflecting estrogen secretion during menopause, animal models specifically expressing ER $(E R \beta$ and $G P R 30$ ) only in selected cells and tissues relevant to the pathogenesis of atherosclerosis (e.g. smooth muscle cell, macrophage, and dendritic cell), as well as systematic assessment of the pro- or anti-atherogenic effects of various concentrations of natural estrogens and synthetic ER agonists will be necessary to address these questions.

\section{Declaration of interest}

The author declares that there is no conflict of interest that could be perceived as prejudicing the impartiality of the review.

\section{Funding}

This work was supported by a grant IDEAS RBID08777T from the Italian Ministry of Education, Universities and Research and intramural resources of the Center for Laboratory Medicine.

\section{References}

Aavik E, du Toit D, Myburgh E, Frösen J \& Hayry P 2001 Estrogen receptor $\beta$ dominates in baboon carotid after endothelial denudation injury. Molecular and Cellular Endocrinology 182 91-98. (doi:10.1016/S0303-7207(01)00552-4)

Adams MR, Golden DL, Anthony MS, Register TC \& Williams JK 2002a The inhibitory effect of soy protein isolate on atherosclerosis in mice does not require the presence of LDL receptors or alteration of plasma lipoproteins. Journal of Nutrition 132 43-49.

Adams MR, Golden DL, Register TC, Anthony MS, Hodgin JB, Maeda N \& Williams JK $2002 b$ The atheroprotective effect of dietary soy isoflavones in apolipoprotein $\mathrm{E}-/-$ mice requires the presence of estrogen receptor- $\alpha$. Arteriosclerosis, Thrombosis, and Vascular Biology 22 1859-1864. (doi:10.1161/01.ATV.0000042202. 42136.D0)

Adamski J, Ma Z, Nozell S \& Benveniste EN 2004 17ß-Estradiol inhibits class II major histocompatibility complex (MHC) expression: influence on histone modifications and cbp recruitment to the class II MHC promoter. Molecular Endocrinology 18 1963-1974. (doi:10.1210/me.2004-0098)

Akarasereenont P, Techatraisak K, Thaworn A \& Chotewuttakorn S 2000 The induction of cyclooxygenase- 2 by $17 \beta$-estradiol in endothelial cells is mediated through protein kinase C. Inflammation Research 49 460-465. (doi:10.1007/s000110050617)

Allred KF, Smart EJ \& Wilson ME 2006 Estrogen receptor- $\alpha$ mediates gender differences in atherosclerosis induced by HIV protease inhibitors. Journal of Biological Chemistry 281 1419-1425. (doi:10.1074/jbc.M506046200)

Alvarez RJ, Gips SJ, Moldovan N, Wilhide CC, Milliken EE, Hoang AT, Hruban RH, Silverman HS, Dang CV \& Goldschmidt-Clermont PJ $199717 \beta$-Estradiol inhibits apoptosis of endothelial cells. Biochemical and Biophysical Research Communications 237 372-381. (doi:10.1006/ bbrc.1997.7085)

Alvarez A, Hermenegildo C, Issekutz AC, Esplugues JV \& Sanz MJ 2002 Estrogens inhibit angiotensin II-induced leukocyte-endothelial cell interactions in vivo via rapid endothelial nitric oxide synthase and cyclooxygenase activation. Circulation Research 91 1142-1150. (doi:10.1161/01.RES.0000046018.23605.3E)

Arnal JF, Fontaine C, Billon-Galés A, Favre J, Laurell H, Lenfant F \& Gourdy P 2010 Estrogens receptors and endothelium. Arteriosclerosis, Thrombosis, and Vascular Biology 30 1506-1512. (doi:10.1161/ ATVBAHA.109.191221) 
Badeau RM, Metso J, Tikkanen MJ \& Jauhiainen M $2007 a$ High density lipoprotein-associated $17 \beta$-estradiol fatty acyl ester uptake by Fu $5 \mathrm{AH}$ hepatoma cells: implications of the roles of scavenger receptor class $\mathrm{B}$, type I and the low-density lipoprotein receptor. Biochimica et Biophysica Acta 1171 1329-1344.

Badeau RM, Vihma V, Mikkola TS, Tittinen A \& Tikkanen MJ $2007 b$ Estradiol fatty acid esters in adipose tissue and serum of pregnant and pre- and postmenopausal women. Journal of Clinical Endocrinology and Metabolism 92 4327-4331. (doi:10.1210/jc.20071372)

Badeau RM, Metso J, Wähälä K, Tikkanen MJ \& Jauhiainen M 2009 Human macrophage cholesterol efflux potential is enhanced by HDL-associated $17 \beta$-estradiol fatty acyl esters. Journal of Steroid Biochemistry and Molecular Biology 116 44-49. (doi:10.1016/j.jsbmb. 2009.04.008)

Barchiesi F, Jackson EK, Fingerle J, Gillespie DG, Odermatt B \& Dubey RK 2006 2-Methoxyestradiol, an estradiol metabolite, inhibits neointima formation and smooth muscle cell growth via double blocade of the cell cycle. Circulation Research 99 266-274. (doi:10.1161/01.RES.0000233318.85181.2e)

Bellosta S, Baetta R, Canavesi M, Comparato C, Granata A, Monetti M, Cairoli F, Eberini I, Puglisi L \& Corsini A 2007 Raloxifene inhibits matrix metalloproteinases expression and activity in macrophages and smooth muscle cells. Pharmacological Research 56 160-167. (doi:10.1016/j.phrs.2007.05.004)

Billon-Galés A, Fontaine C, Douin-Echinard V, Delpy L, Berges H, Calippe B, Lenfant F, Laurell H, Guéry JC, Gourdy P et al. 2009a Endothelial estrogen receptor- $\alpha$ plays a crucial role in the atheroprotective action of $17 \beta$-estradiol in low-density lipoprotein receptor-deficient mice. Circulation 120 2567-2576. (doi:10.1161/ CIRCULATIONAHA.109.898445)

Billon-Galés A, Fontaine C, Filipe C, Douin-Echinard V, Fouque MJ, Flouriot G, Gourdy P, Lenfant F, Laurell H, Krust A et al. $2009 b$ The transactivating function 1 of estrogen receptor $\alpha$ is dispensable for the vasculoprotective actions of 17ß-estradiol. PNAS 106 2053-2058. (doi:10.1073/pnas.0808742106)

Billon-Galés A, Krust A, Fontaine C, Abot A, Flouriot G, Toutain C, Berges H, Gadeau AP, Lenfant F, Gourdy P et al. 2011 Activation function 2 (AF2) of estrogen receptor- $\alpha$ is required for the atheroprotective action of estradiol but not to accelerate endothelial healing. PNAS 108 13311-13316. (doi:10.1073/pnas. 1105632108)

Bolego C, Rossoni G, Fadini GP, Vegeto E, Pinna C, Albiero M, Boscaro E, Agostini C, Avogaro A, Galon RM et al. 2010 Selective estrogen receptor- $\alpha$ agonist provides widespread heart and vascular protection with enhanced endothelial progenitor cell mobilization in the absence of uterotrophic action. FASEB Journal 24 2262-2272. (doi:10.1096/fj.09-139220)

Bourassa PA, Milos PM, Gaynor BJ, Breslow JL \& Aiello RJ 1996 Estrogen reduces atherosclerotic lesion development in apolipoprotein E-deficient mice. PNAS 93 10022-10027. (doi:10.1073/ pnas.93.19.10022)

Bourghardt J, Bergström G, Krettek A, Sjöberg S, Borén J \& Tivesten A 2007 The endogenous estradiol metabolite 2-methoxyestradiol reduces atherosclerotic lesion formation in female apolipoprotein E-deficient mice. Endocrinology 148 4128-4132. (doi:10.1210/en. 2007-0259)

Bourghardt J, Wilhelmson AS, Alexanderson C, De Gendt K, Verhoeven G, Krettek A, Ohlsson C \& Tivesten A 2010 Androgen receptor-dependent and independent atheroprotection by testosterone in male mice. Endocrinology 151 5428-5437. (doi:10.1210/en.2010-0663)

Broughton BR, Miller AA \& Sobey CG 2010 Endotheliumdependent relaxation by $\mathrm{G}$ protein-coupled receptor 30 agonists in rat carotid arteries. American Journal of Physiology. Heart and Circulatory Physiology 298 H1055-H1061. (doi:10.1152/ajpheart. 00878.2009)
Bruce-Keller AJ, Keeling JL, Keller JN, Huang FF, Camondola S \& Mattson MP 2000 Antiinflammatory effects of estrogen on microglial activation. Endocrinology 141 3646-3656. (doi:10.1210/ en.141.10.3646)

Burek M, Arias-Loza PA, Roewer N \& Förster CY 2010 Claudin-5 as a novel estrogen target in vascular endothelium. Arteriosclerosis, Thrombosis, and Vascular Biology 30 298-304. (doi:10.1161/ATVBAHA.109.197582)

Calippe B, Douin-Echinard V, Laffargue M, Laurell H, Rana-Poussine V, Pipy B, Guéry JC, Bayard F, Arnal JF \& Gourdy P 2008 Chronic estradiol administration in vivo promotes the proinflammatory response of macrophages to TLR4 activation: involvement of the phosphatidylinositol 3-kinase pathway. Journal of Immunology 180 7980-7988.

Calippe B, Douin-Echinard V, Delpy L, Laffargue M, Lélu K, Krust A, Pipy B, Bayard F, Arnal JF, Guéry JC et al. 2010 17ß-Estradiol promotes TLR4-triggered proinflammatory mediator production through direct estrogen receptor $\alpha$ signaling in macrophages in vivo. Journal of Immunology 185 1169-1176. (doi:10.4049/ jimmunol.0902383)

Cann JA, Register TC, Adams MR, St Clair RW, Espeland MA \& Williams JK 2008 Timing of estrogen replacement influences atherosclerosis progression and plaque leukocyte populations in ApoE - / - mice. Atherosclerosis 201 43-52. (doi:10.1016/j.atherosclerosis.2008.01.018)

Carbajal JM \& Schaeffer RC Jr $1998 \mathrm{H}_{2} \mathrm{O}_{2}$ and genistein differentially modulate protein tyrosine phosphorylation, endothelial morphology, and monolayer barrier function. Biochemical and Biophysical Research Communications 249 461-466. (doi:10.1006/bbrc. 1998.9172)

Carreras E, Turner S, Paharkova-Vatchkova V, Mao A, Dascher C \& Kovats S 2008 Estradiol acts directly on bone marrow myeloid progenitors to differentially regulate GM-CSF or Flt3 ligandmediated dendritic cell differentiation. Journal of Immunology 180 727-738.

Carreras E, Turner S, Frank MB, Knowlton N, Osban J, Centola M, Park CG, Simmons A, Alberola-Ila J \& Kovats S 2010 Estrogen receptor signaling promotes dendritic cell differentiation by increasing expression of the transcription factor IRF4. Blood 115 238-246. (doi:10.1182/blood-2009-08-236935)

Carruba G, D'Agostino P, Miele M, Calabrò M, Barbera C, Bella GD, Milano S, Ferlazzo V, Caruso R, Rosa ML et al. 2003 Estrogen regulates cytokine production and apoptosis in PMA-differentiated, macrophage-like U937 cells. Journal of Cellular Biochemistry 90 187-196. (doi:10.1002/jcb.10607)

Chen JR, Haley RL, Hidestrand M, Shankar K, Liu X, Lumpkin CK, Simpson PM, Badger T \& Ronis MJ 2006 Estradiol protects against ethanol-induced bone loss by inhibiting up-regulation of receptor activator of nuclear factor-kappaB ligand in osteoblasts. Journal of Pharmacology and Experimental Therapeutics 319 1182-1190. (doi:10.1124/jpet.106.109454)

Cheng W, Lau OD \& Abumrad NA 1999 Two antiatherogenic effects of progesterone on human macrophages; inhibition of cholesteryl ester synthesis and block of its enhancement by glucocorticoids. Journal of Clinical Endocrinology and Metabolism 84 265-271. (doi:10.1210/jc.84.1.265)

Chi OZ, Barsoum S, Wen Y, Liu X \& Weiss HR 2004 17ß-Estradiol prevents blood-brain barrier disruption induced by VEGF. Hormone and Metabolic Research 36 272-276. (doi:10.1055/s-2004-814478)

Chow RW, Handelsman DJ \& Ng MK 2010 Minireview: rapid actions of sex steroids in the endothelium. Endocrinology 151 2411-2422. (doi:10.1210/en.2009-1456)

Clarke M \& Bennett M 2006 The emerging role of vascular smooth muscle cell apoptosis in atherosclerosis and plaque stability. American Journal of Nephrology 26 531-535. (doi:10.1159/000097815)

Corcoran MP, Lichtenstein AH, Meydani M, Dillard A, Schaefer EJ \& Lamon-Fava S 2011 The effect of 17ß-estradiol on cholesterol 
content in human macrophages is influenced by the lipoprotein milieu. Journal of Molecular Endocrinology 47 109-117. (doi:10.1530/ JME-10-0158)

Crisafulli C, Bruscoli S, Esposito E, Mazzon E, Di Paola R, Genovese T, Bramanti P, Migliorati G \& Cuzzocrea S 2009 PPAR- $\alpha$ contributes to the anti-inflammatory activity of $17 \beta$-estradiol. Journal of Pharmacology and Experimental Therapeutics 331 796-807. (doi:10.1124/jpet. 109.156646)

Dai-Do D, Espinosa E, Liu G, Rabelink TJ, Julmy F, Yang Z, Mahler F \& Lüscher TF 1996 17ß-Estradiol inhibits proliferation and migration of human vascular smooth muscle cells: similar effects in cells from postmenopausal females and in males. Cardiovascular Research $\mathbf{3 2}$ 980-985.

Delarue F, Daunes S, Elhage R, Garcia A, Bayard F \& Faye J 1998 Estrogens modulate bovine vascular endothelial cell permeability and HSP25 expression concomitantly. American Journal of Physiology. Heart and Circulatory Physiology 275 H1011-H1015.

Delpy L, Douin-Echinard V, Garidou L, Bruand C, Saoudi A \& Guéry JC 2005 Estrogen enhances susceptibility to experimental autoimmune myasthenia gravis by promoting type 1-polarized immune responses. Journal of Immunology 175 $5050-5057$.

Deshpande R, Khalili H, Pergolizzi RG, Michael SD \& Chang MD 1997 Estradiol down-regulates LPS-induced cytokine production and NFkB activation in murine macrophages. American Journal of Reproductive Immunology 38 46-54. (doi:10.1111/j.1600-0897.1997. tb00275.x)

Ding Q, Gros R, Limbird LE, Chorazyczewski J \& Feldman RD 2009 Estradiol-mediated ERK phosphorylation and apoptosis in vascular smooth muscle cells requires GPR30. American Journal of Physiology. Cellular Physiology 297 C1178-C1187. (doi:10.1152/ajpcell.00185. 2009)

Doran AC, Meller N \& McNamara CA 2008 Role of smooth muscle cells in the initiation and early progression of atherosclerosis. Arteriosclerosis, Thrombosis, and Vascular Biology 28 812-819. (doi:10.1161/ ATVBAHA.107.159327)

Douin-Echinard V, Laffont S, Seillet C, Delpy L, Krust A, Chambon P, Gourdy P, Arnal JF \& Guéry JC 2008 Estrogen receptor $\alpha$, but not beta, is required for optimal dendritic cell differentiation and CD40-induced cytokine production. Journal of Immunology 180 3661-3669.

Dubey RK \& Jackson EK 2009 Potential vascular actions of 2-methoxyestradiol. Trends in Endocrinology and Metabolism 20 374-379. (doi:10.1016/j.tem.2009.04.007)

Egan KM, Lawson JA, Fries S, Koller B, Rader DJ, Smyth EM \& Fitzgerald GA 2004 COX-2-derived prostacyclin confers atheroprotection on female mice. Science 306 1954-1957. (doi:10.1126/ science.1103333)

Elhage R, Arnal JF, Pieraggi MT, Duverger N, Fiévet C, Faye JC \& Bayard F 1997 a $17 \beta$-Estradiol prevents fatty streak formation in apolipoprotein E-deficient mice. Arteriosclerosis, Thrombosis, and Vascular Biology 17 2679-2684. (doi:10.1161/01.ATV.17.11. 2679)

Elhage R, Bayard F, Richard V, Holvoet P, Duverger N, Fiévet C \& Arnal JF $1997 b$ Prevention of fatty streak formation of $17 \beta$-estradiol is not mediated by the production of nitric oxide in apolipoprotein E-deficient mice. Circulation 96 3048-3052.

Elhage R, Clamens S, Besnard S, Mallat Z, Tedgui A, Arnal J, Maret A \& Bayard F 2001 Involvement of interleukin-6 in atherosclerosis but not in the prevention of fatty streak formation by $17 \beta$-estradiol in apolipoprotein E-deficient mice. Atherosclerosis 156 315-320. (doi:10.1016/S0021-9150(00)00682-1)

Esaki T, Hayashi T, Muto E, Kano H, Kumar TN, Asai Y, Sumi D \& Iguchi A 2000 Expression of inducible nitric oxide synthase and Fas/Fas ligand correlates with the incidence of apoptotic cell death in atheromatous plaques of human coronary arteries. Nitric Oxide 4 561-571. (doi:10.1006/niox.2000.0311)
Espinosa E, Oemar BS \& Lüscher TF 1996 17ß-Estradiol and smooth muscle cell proliferation in aortic cells of male and female rats. Biochemical and Biophysical Research Communications 221 8-14. (doi:10.1006/bbrc.1996.0535)

Fenoy FJ, Hernandez ME, Hernandez M, Quesada T, Salom MG \& Hernandez I 2010 Acute effects of 2-methoxyestradiol on endothelial aortic NO release in male and ovarectomized female rats. Nitric Oxide 23 12-19. (doi:10.1016/j.niox.2010.03.002)

Florian M \& Magder S 2008 Estrogen decreases TNF- $\alpha$ and oxidized LDL induced apoptosis in endothelial cells. Steroids 73 47-58. (doi:10.1016/j.steroids.2007.08.010)

Frazier-Jessen MR \& Kovacs EJ 1995 Estrogen modulation of $\mathrm{JE} /$ monocyte chemoattractant protein-1 mRNA expression in murine macrophages. Journal of Immunology 154 1838-1845.

Freudenberger T, Oppermann M, Heim HK, Mayer P, Kojda G, Schrör K \& Fischer JW 2010 Proatherogenic effects of estradiol in a model of accelerated atherosclerosis in ovariectomized ApoEdeficient mice. Basic Research in Cardiology 105 479-486. (doi:10.1007/s00395-010-0091-6)

Friedrich EB, Clever YP, Wassmann S, Hess C \& Nickenig G 2006 $17 \beta$-Estradiol inhibits monocyte adhesion via down-regulation of Rac1 GTPase. Journal of Molecular and Cellular Cardiology 40 87-95. (doi:10.1016/j.yjmcc.2005.10.007)

Fujimoto J, Sakaguchi H, Hirose R \& Tamaya T 1998 Sex steroidal regulation of vessel permeability associated with vessel endothelial cadherin (V-cadherin). Journal of Steroid Biochemistry and Molecular Biology 67 25-32. (doi:10.1016/S0960-0760(98)00069-7)

García Palacios V, Robinson LJ, Borysenko CW, Lehmann T, Kalla SE \& Blair HC 2005 Negative regulation of RANKL-induced osteoclastic differentiation in RAW264.7 cells by estrogen and phytoestrogens. Journal of Biological Chemistry 280 13720-13727. (doi:10.1074/jbc. M410995200)

Gardner G, Banka CL, Roberts KA, Mullick AE \& Rutledge JC 1999 Modified LDL-mediated increases in endothelial layer permeability are attenuated with $17 \beta$-estradiol. Arteriosclerosis, Thrombosis, and Vascular Biology 19 854-861. (doi:10.1161/01.ATV. 19.4.854)

Geraldes P, Sirois MG, Bernatchez PN \& Tanguay JF 2002 Estrogen regulation of endothelial and smooth muscle cell migration and proliferation: role of $\mathrm{p} 38$ and p42/44 mitogen-activated protein kinase. Arteriosclerosis, Thrombosis, and Vascular Biology 22 1585-1590. (doi:10.1161/01.ATV.0000035393.11854.6A)

Geraldes P, Sirois MG \& Tanguay JF 2003 Specific contribution of estrogen receptors on mitogen-activated protein kinase pathways and vascular cell activation. Circulation Research 93 399-405. (doi:10.1161/01.RES.0000088640.18462.42)

Geraldes P, Gagnon S, Hadjadj S, Merhi Y, Sirois MG, Cloutier I \& Tanguay JF 2006 Estradiol blocks the induction of CD40 and CD40L expression on endothelial cells and prevents neutrophil adhesion: an ER $\alpha$-mediated pathway. Cardiovascular Research 71 566-573. (doi:10.1016/j.cardiores.2006.05.015)

Ghanam K, Lavagna C, Burgaud JL, Javellaud J, Ea-Kim L \& Oudart N 2000 Involvement of cyclooxygenase 2 in the protective effect of $17 \beta$-estradiol on hypercholesterolemic rabbit aorta. Biochemical and Biophysical Research Communications 275 696-703. (doi:10.1006/bbrc. 2000.3278)

Ghisletti S, Meda C, Maggi A \& Vegeto E 2005 17ß-Estradiol inhibits inflammatory gene expression by controlling NF- $\mathrm{KB}$ intracellular localization. Molecular and Cellular Biology 25 2957-2968. (doi:10. 1128/MCB.25.8.2957-2968.2005)

Gibson LL, Hahner L, Osborne-Lawrence S, German Z, Wu KK, Chambliss KL \& Shaul PW 2005 Molecular basis of estrogeninduced cyclooxygenase type 1 upregulation in endothelial cells. Circulation Research 96 518-525. (doi:10.1161/01.RES.0000158967. 96231.88)

Gourdy P, Mallat Z, Castano C, Garmy-Susini B, Mac Gregor JL, Tedgui A, Arnal JF \& Bayard F 2003 The atheroprotective effect of 
$17 \beta$-estradiol is not altered in P-selectin- or ICAM-1-deficient hypercholesterolemic mice. Atherosclerosis 166 41-48. (doi:10.1016/ S0021-9150(02)00322-2)

Grasselli A, Nanni S, Colussi C, Aiello A, Benvenuti V, Ragone G, Moretti F, Sacchi A, Bacchetti S, Gaetano C et al. 2008 Estrogen receptor- $\alpha$ and endothelial nitric oxide synthase nuclear complex regulates transcription of human telomerase. Circulation Research 103 34-42. (doi:10.1161/CIRCRESAHA.107.169037)

Haas E, Bhattacharya I, Brailoiu E, Damjanović M, Brailoiu GC, Gao X, Mueller-Guerre L, Marjon NA, Gut A, Minotti R et al. 2009 Regulatory role of $\mathrm{G}$ protein-coupled estrogen receptor for vascular function and obesity. Circulation Research 104 288-291. (doi:10.1161/CIRCRESAHA.108.190892)

Hämäläinen M, Nieminen R, Vuorela P, Heinonen M \& Moilanen E 2007 Anti-inflammatory effects of flavonoids: genistein, kaempferol, quercetin, and daidzein inhibit STAT- 1 and NF- $\kappa$ B activations, whereas flavone, isorhamnetin, naringenin, and pelargonidin inhibit only NF- $\kappa$ B activation along with their inhibitory effect on iNOS expression and NO production in activated macrophages. Mediators of Inflammation ID45673 1-10. (doi:10.1155/2007/45673)

Hayashi T, Jayachandran M, Sumi D, Thakur NK, Esaki T, Muto E, Kano H, Asai Y \& Iguchi A 2000 Physiological concentration of $17 \beta$-estradiol retards the progression of severe atherosclerosis induced by a high-cholesterol diet plus balloon catheter injury: role of NO. Arteriosclerosis, Thrombosis, and Vascular Biology 20 1613-1621. (doi:10.1161/01.ATV.20.6.1613)

Hayashi T, Matsui-Hirai H, Miyazaki-Akita A, Fukatsu A, Funami J, Ding QF, Kamalanathan S, Hattori Y, Ignarro LJ \& Iguchi A 2006 Endothelial cellular senescence is inhibited by nitric oxide: implications in atherosclerosis associated with menopause and diabetes. PNAS 103 17018-17023. (doi:10.1073/pnas.0607873103)

Helisten H, Höckerstedt A, Wähälä K, Tiitinen A, Adlercreutz H, Jauhiainen M \& Tikkanen MJ 2001 Accumulation of high-density lipoprotein-derived estradiol-17 $\beta$ fatty acid esters in low-density lipoprotein particles. Journal of Clinical Endocrinology and Metabolism 86 1294-1300. (doi:10.1210/jc.86.3.1294)

Höckerstedt A, Tikkanen MJ \& Jauhiainen M 2002 LCAT facilitates transacylation of $17 \beta$-estradiol in the presence of HDL3 subfraction. Journal of Lipid Research 43 392-397.

Höckerstedt A, Jauhiainen M \& Tikkanen MJ 2004 Lecithin/ cholesterol acyltransferase induces estradiol esterification in high-density lipoprotein increasing its anti-oxidant potential. Journal of Clinical Endocrinology and Metabolism 89 5088-5093. (doi:10.1210/jc.2004-0141)

Hodgin JB, Krege JH, Reddick RL, Korach KS, Smithies O \& Maeda N 2001 Estrogen receptor $\alpha$ is a major mediator of $17 \beta$-estradiol's atheroprotective effects on lesion size in Apoe $-/-$ mice. Journal of Clinical Investigation 107 333-340. (doi:10.1172/JCI11320)

Hodgin JB, Knowles JW, Kim HS, Smithies O \& Maeda N 2002 Interactions between endothelial nitric oxide synthase and sex hormones in vascular protection in mice. Journal of Clinical Investigation 109 541-548.

Holm P, Korsgaard N, Shalmi M, Andersen HL, Hougaard P, Skouby SO \& Stender S 1997 Significant reduction of the antiatherogenic effect of estrogen by long-term inhibition of nitric oxide synthesis in cholesterol-clamped rabbits. Journal of Clinical Investigation 100 821-828. (doi:10.1172/JCI119597)

Hong HJ, Liu JC, Chan P, Juan SH, Loh SH, Lin JG \& Cheng TH 2004 $17 \beta$-Estradiol downregulates angiotensin-II-induced endothelin-1 gene expression in rat aortic smooth muscle cells. Journal of Biomedical Sciences 11 27-36.

Hsieh YC, Frink M, Thobe BM, Hsu JT, Choudhry MA, Schwacha MG, Bland KI \& Chaudry IH 2007 17 $\beta$-Estradiol downregulates Kupffer cell TLR4-dependent p38 MAPK pathway and normalizes inflammatory cytokine production following trauma-hemorrhage. Molecular Immunology 44 2165-2172. (doi:10.1016/j.molimm.2006. 11.019)
Hulley S, Grady D, Bush T, Furberg C, Herrington D, Riggs B \& Vittinghoff E 1998 Randomized trial of estrogen plus progestin for secondary prevention of coronary heart disease in postmenopausal women. Heart and Estrogen/Progestin Replacement Study (HERS) Research Group. Journal of the American Medical Association 280 605-613. (doi:10.1001/jama.280.7.605)

Hwang KC, Lee KH \& Jang Y 2002 Inhibition of MEK1,2/ERK mitogenic pathway by estrogen with antiproliferative properties in rat aortic smooth muscle cells. Journal of Steroid Biochemistry and Molecular Biology 80 85-90. (doi:10.1016/S0960-0760(01)00169-8)

Javeshghani D, Sairam MR, Neves MF, Schiffrin EL \& Touyz RM 2006 Angiotensin II induces vascular dysfunction without exacerbating blood pressure elevation in a mouse model of menopauseassociated hypertension. Journal of Hypertension 24 1365-1373. (doi:10.1097/01.hjh.0000234117.25401.f8)

Javeshghani D, Sairam MR, Schiffrin EL \& Touyz RM 2007 Increased blood pressure, vascular inflammation, and endothelial dysfunction in androgen-deficient follitropin receptor knockout male mice. Journal of the American Society of Hypertension 1353-361. (doi:10.1016/ j.jash.2007.06.003)

Jiang P, Xu J, Zheng S, Huang J, Xiang Q, Fu X \& Wang T 2010 $17 \beta$-Estradiol down-regulates lipopolysaccharide-induced MCP-1 production and cell migration in vascular smooth muscle cells. Journal of Molecular Endocrinology 45 87-97. (doi:10.1677/JME-090166)

Jun SS, Chen Z, Pace MC \& Shaul PW 1998 Estrogen upregulates cyclooxygenase-1 gene expression in ovine fetal pulmonary artery endothelium. Journal of Clinical Investigation 102 176-183. (doi:10.1172/JCI2034)

Kappert K, Caglayan E, Huntgeburth M, Bäumer AT, Sparwel J, Uebel M \& Rosenkranz S 2006 17 $\beta$-Estradiol attenuates PDGF signaling in vascular smooth muscle cells at the postreceptor level. American Journal of Physiology. Heart and Circulatory Physiology 290 H538-H546. (doi:10.1152/ajpheart.00240.2005)

Kawagoe J, Ohmichi M, Tsutsumi S, Ohta T, Takahashi K \& Kurachi H 2007 Mechanism of the divergent effects of estrogen on the cell proliferation of human umbilical endothelial versus aortic smooth muscle cells. Endocrinology 148 6092-6099. (doi:10.1210/en.20070188)

Kawasaki T, Choudhry MA, Suzuki T, Schwacha MG, Bland KI \& Chaudry IH 2008 17ß-Estradiol's salutary effects on splenic dendritic cell functions following trauma-hemorrhage are mediated via estrogen receptor- $\alpha$. Molecular Immunology 45 376-385. (doi:10.1016/j.molimm.2007.06.148)

Kolodgie FD, Jacob A, Wilson PS, Carlson GC, Farb A, Verma A \& Virmani R 1996 Estradiol attenuates directed migration of vascular smooth muscle cells in vitro. American Journal of Pathology 148 969-976.

Krom YD, Pires NM, Jukema JW, de Vries MR, Frants RR, Havekes LM, van Dijk KW \& Quax PH 2007 Inhibition of neointima formation by local delivery of estrogen receptor $\alpha$ and $\beta$ specific agonists. Cardiovascular Research 73 217-226. (doi:10.1016/j.cardiores.2006. 10.024)

Kurokawa A, Azuma K, Mita T, Toyofuku Y, Fujitani Y, Hirose T, Iwabuchi K, Ogawa H, Takeda S, Kawamori R et al. 2007 2-Methoxyestradiol reduces monocyte adhesion to aortic endothelial cells. Endocrine Journal 54 1027-1031. (doi:10.1507/ endocrj.K07E-034)

Lea CK, Sarma U \& Flanagan AM 1999 Macrophage colony stimulating-factor transcripts are differentially regulated in rat bone-marrow by gender hormones. Endocrinology 140 273-279. (doi:10.1210/en.140.1.273)

Lee SA, Park SH \& Kim BC 2008 Raloxifene, a selective estrogen receptor modulator, inhibits lipopolysaccharide-induced nitric oxide production by inhibiting the phosphatidylinositol 3-kinase/Akt/nuclear factor-kappa B pathway in RAW264.7 macrophage cells. Molecular Cells 26 48-52. 
Lerner DJ \& Kannel WB 1986 Patterns of coronary heart disease morbidity and mortality in the sexes: a 26-year follow-up of the Framingham population. American Heart Journal 111 383-390. (doi:10.1016/0002-8703(86)90155-9)

Ley K, Miller YI \& Hedrick CC 2011 Monocyte and macrophage dynamics during atherogenesis. Arteriosclerosis, Thrombosis, and Vascular Biology 31 1506-1516. (doi:10.1161/ATVBAHA.110. 221127)

Li X, Xu Y, Ma L, Sun L, Fu G \& Hou Y 2009 17ß-Estradiol enhances the response of plasmacytoid dendritic cell to CpG. PLoS ONE 4 e8412. (doi:10.1371/journal.pone.0008412)

Lindner V, Kim SK, Karas RH, Kuiper GG, Gustafsson JA \& Mendelsohn ME 1998 Increased expression of estrogen receptor- $\beta$ mRNA in male blood vessels after vascular injury. Circulation Research 83 224-229.

Ling S, Little PJ, Williams MR, Dai A, Hashimura K, Liu JP, Komesaroff PA \& Sudhir K 2002 High glucose abolishes the antiproliferative effect of $17 \beta$-estradiol in human vascular smooth muscle cells. American Journal of Physiology. Endocrinology and Metabolism 282 E746-E751.

Ling S, Zhou L, Li H, Dai A, Liu JP, Komesaroff PA \& Sudhir K 2006 Effects of $17 \beta$-estradiol on growth and apoptosis in human vascular endothelial cells: influence of mechanical strain and tumor necrosis factor- $\alpha$. Steroids 71 799-808. (doi:10.1016/j.steroids.2006.05.010)

Liu WL, Guo X \& Guo ZG 2002 Estrogen prevents bovine aortic endothelial cells from TNF- $\alpha$-induced apoptosis via opposing effects on p38 and p44/42 CCDPK. Acta Pharmacologica Sinica 23 213-218.

Liu D, Jiang H \& Grange RW 2005 Genistein activates the $3^{\prime}, 5^{\prime}$-cyclic adenosine monophosphate signaling pathway in vascular endothelial cells and protects endothelial barrier function. Endocrinology 146 1312-1320. (doi:10.1210/en.2004-1221)

Lou H, Kodama T, Zhao YJ, Maurice P, Wang YN, Katz N \& Foegh ML 1996 Inhibition of transplant coronary arteriosclerosis in rabbits by chronic estradiol treatment is associated with abolition of MHC class II antigen expression. Circulation 94 3355-3361.

Lu A, Frink M, Choudhry MA, Schwacha MG, Hubbard WJ, Rue LW III, Bland KI \& Chaudry IH 2006 Mitochondria play an important role in $17 \beta$-estradiol attenuation of $\mathrm{H}(2) \mathrm{O}(2)$-induced rat endothelial cell apoptosis. American Journal of Physiology. Endocrinology and Metabolism 292 E585-E593. (doi:10.1152/ajpendo. 00413.2006)

Maffei L, Murata Y, Rochira V, Tubert G, Aranda C, Vazquez M, Clyne CD, Davis S, Simpson ER \& Carani C 2004 Dysmetabolic syndrome in a man with a novel mutation of the aromatase gene: effects of testosterone, alendronate, and estradiol treatment. Journal of Clinical Endocrinology and Metabolism 89 61-70. (doi:10.1210/jc.2003-030313)

Maggiolini M \& Picard D 2010 The unfolding stories of GPR30, a new membrane-bound estrogen receptor. Journal of Endocrinology 204 105-114. (doi:10.1677/JOE-09-0242)

Martin-McNulty B, Tham DM, da Cunha V, Ho JJ, Wilson DW, Rutledge JC, Deng GG, Vergona R, Sullivan ME \& Wang YX 2003 $17 \beta$-Estradiol attenuates development of angiotensin II-induced aortic abdominal aneurysm in apolipoprotein E-deficient mice. Arteriosclerosis, Thrombosis, and Vascular Biology 23 1627-1632. (doi:10.1161/01.ATV.0000085842.20866.6A)

Mayer LP, Dyer CA, Eastgard RL, Hoyer PB \& Banka CL 2005 Atherosclerotic lesion development in a novel ovary-intact mouse model of perimenopause. Arteriosclerosis, Thrombosis, and Vascular Biology 25 1910-1916. (doi:10.1161/01.ATV.0000175767.46520.6a)

McCrohon JA, Nakhla S, Jessup W, Stanley KK \& Celermajer DS 1999 Estrogen and progesterone reduce lipid accumulation in human monocyte-derived macrophages: a sex-specific effect. Circulation 100 2319-2325.

Mikkola T, Turunen P, Avela K, Orpana A, Viinikka L \& Ylikorkala O 1995 17ß-Estradiol stimulates prostacyclin, but not endothelin-1, production in human vascular endothelial cells. Journal of Clinical Endocrinology and Metabolism 80 1832-1836. (doi:10.1210/jc.80.6. 1832)

Mikkola T, Ranta V, Orpana A, Ylikorkala O \& Viinikka L 1996 Effect of physiological concentrations of estradiol on PGI2 and NO in endothelial cells. Maturitas 25 141-147. (doi:10.1016/03785122(96)01057-2)

Montagna P, Brizzolara R, Soldano S, Pizzorni C, Sulli A \& Cutolo M 2009 Sex hormones and leflunomide treatment of human macrophage cultures: effects on apoptosis. International Journal of Clinical and Experimental Medicine 2 221-232.

Moore KJ \& Tabas I 2011 Macrophages in the pathogenesis of atherosclerosis. Cell 145 341-355. (doi:10.1016/j.cell.2011.04.005)

Mor G, Sapi E, Abrahams VM, Rutherford T, Song J, Hao XY, Muzaffar S \& Kohen F 2003 Interaction of the estrogen receptors with the Fas ligand promoter in human monocytes. Journal of Immunology 170 114-122.

Mori M, Tsukahara F, Yoshioka T, Irie K \& Ohta H 2004 Suppression by $17 \beta$-estradiol of monocyte adhesion to vascular endothelial cells is mediated by estrogen receptors. Life Sciences 75 599-609. (doi:10.1016/S0024-3205(04)00290-5)

Mori-Abe A, Tsutsumi S, Takahashi K, Toya M, Yoshida M, Du B, Kawagoe J, Nakahara K, Takahashi T, Ohmichi M et al. 2003 Estrogen and raloxifene induce apoptosis by activating p38 mitogen-activated protein kinase cascade in synthetic vascular smooth muscle cells. Journal of Endocrinology 178 417-426. (doi:10.1677/joe.0.1780417)

Mukherjee TK, Dinh H, Chaudhuri G \& Nathan L 2002 Testosterone attenuates expression of vascular cell adhesion molecule-1 by conversion to estradiol by aromatase in endothelial cells: implications in atherosclerosis. PNAS 99 4055-4060. (doi:10.1073/pnas. 052703199)

Mukherjee TK, Nathan L, Dinh H, Reddy ST \& Chaudhuri G 2003 17-Epiestriol, an estrogen metabolite, is more potent than estradiol in inhibiting vascular cell adhesion molecule 1 (VCAM-1) mRNA expression. Journal of Biological Chemistry 278 11746-11752. (doi:10.1074/jbc.M207800200)

Muller M, van den Beld AW, Bots ML, Grobbee DE, Lamberts SW \& van der Schouw YT 2004 Endogenous sex hormones and progression of carotid atherosclerosis in elderly men. Circulation 109 2074-2079. (doi:10.1161/01.CIR.0000125854.51637.06)

Murphy AJ, Guyre PM \& Pioli PA 2010 Estradiol suppresses NF-kappa B activation through coordinated regulation of let-7a and miR-125b in primary human macrophages. Journal of Immunology 184 5029-5037. (doi:10.4049/jimmunol.0903463)

Nakamura T, Imai Y, Matsumoto T, Sato S, Takeuchi K, Igarashi K, Harada Y, Azuma Y, Krust A, Yamamoto Y et al. 2007 Estrogen prevents bone loss via estrogen receptor $\alpha$ and induction of Fas ligand in osteoclasts. Cell 130 811-823. (doi:10.1016/j.cell.2007. 07.025)

Napolitano M, Blotta I, Montali A \& Bravo E 2001 17ß-Estradiol enhances the flux of cholesterol through the cholesteryl ester cycle in human macrophages. Bioscience Reports 21 637-652. (doi:10.1023/ A:1014721026280)

Napolitano M, Calcabrini A, Botham KM \& Bravo E 2002 Role of estrogen in the regulation of cholesteryl ester synthesis in macrophages: the interaction between native and modified low density lipoprotein and human monocyte-derived macrophages. Clinical Biochemistry 35 597-605. (doi:10.1016/S00099120(02)00404-6)

Nascimento CA, Kauser K \& Rubanyi GM 1999 Effect of $17 \beta$-estradiol in hypercholesterolemic rabbits with severe endothelial dysfunction. American Journal of Physiology. Heart and Circulatory Physiology 276 H1788-H1794.

Nathan L, Pervin S, Singh R, Rosenfeld M \& Chaudhuri G 1999 Estradiol inhibits leukocyte adhesion and transendothelial migration in rabbits in vivo: possible mechanisms for gender differences in atherosclerosis. Circulation Research 85 377-385. 
Nathan L, Shi W, Dinh H, Mukherjee TK, Wang X, Lusis AJ \& Chaudhuri G 2001 Testosterone inhibits early atherogenesis by conversion to estradiol: critical role of aromatase. PNAS $\mathbf{9 8}$ 3589-3593. (doi:10.1073/pnas.051003698)

Nettleship JE, Jones TH, Channer KS \& Jones RD 2007 Physiological testosterone replacement therapy attenuates fatty streak formation and improves high-density lipoprotein cholesterol in the Tfm mouse: an effect that is independent of the classic androgen receptor. Circulation 116 2427-2434. (doi:10.1161/CIRCULATIONAHA.107.708768)

Norata GD, Cattaneo P, Poletti A \& Catapano AL 2010 The androgen derivative $5 \alpha$-androstane-3 $\beta, 17 \beta$-diol inhibits tumor necrosis factor $\alpha$ and lipopolysaccharide induced inflammatory response in human endothelial cells and in mice aorta. Atherosclerosis 212 100-106. (doi:10.1016/j.atherosclerosis. 2010.05.015)

Orr AW, Hastings NE, Blackman BR \& Wamhoff BR 2010 Complex regulation and function of the inflammatory smooth muscle cell phenotype in atherosclerosis. Journal of Vascular Research 47 168-180. (doi:10.1159/000250095)

Oviedo PJ, Sobrino A, Laguna-Fernandez A, Novella S, Tarín JJ, García-Pérez MA, Sanchís J, Cano A \& Hermenegildo C 2011 Estradiol induces endothelial cell migration and proliferation through estrogen receptor-enhanced RhoA/ROCK pathway. Molecular and Cellular Endocrinology 335 96-103. (doi:10.1016/j.mce. 2010.06.020)

Pérez-López FR, Chedraui P, Gilbert JJ \& Pérez-Roncero G 2009 Cardiovascular risk in menopausal women and prevalent related co-morbid conditions: facing the post-Women's Health Initiative era. Fertility and Sterility 92 1171-1186. (doi:10.1016/j.fertnstert. 2009.06.032)

Rauschemberger MB, Sandoval MJ \& Massheimer VL 2011 Cellular and molecular actions displayed by estrone on vascular endothelium. Molecular and Cellular Endocrinology 339 136-143. (doi:10.1016/j.mce.2011.04.009)

Rayner K, Chen YX, McNulty M, Simard T, Zhao X, Wells DJ, de Belleroche J \& O'Brien ER 2008 Extracellular release of the atheroprotective heat shock protein 27 is mediated by estrogen and competitively inhibits acLDL binding to scavenger receptor-A. Circulation Research 103 133-141. (doi:10.1161/CIRCRESAHA.108. 172155)

Rayner K, Sun J, Chen YX, McNulty M, Simard T, Zhao X, Wells DJ, de Belleroche J \& O'Brien ER 2009 Heat shock protein 27 protects against atherogenesis via an estrogen-dependent mechanism: role of selective estrogen receptor $\beta$ modulation. Arteriosclerosis, Thrombosis, and Vascular Biology 29 1751-1756. (doi:10.1161/ ATVBAHA.109.193656)

Razmara A, Sunday L, Stirone C, Wang XB, Krause DN, Duckles SP \& Procaccio V 2008 Mitochondrial effects of estrogen are mediated by estrogen receptor $\alpha$ in brain endothelial cells. Journal of Pharmacology and Experimental Therapeutics 325 782-790. (doi:10.1124/jpet.107. 134072)

Register TC \& Adams MR 1998 Coronary artery and cultured aortic smooth muscle cells express mRNA for both the classical estrogen receptor and the newly described estrogen receptor $\beta$. Journal of Steroid Biochemistry and Molecular Biology 64 187-191. (doi:10.1016/ S0960-0760 (97)00155-6)

Rettew JA, Huet YM \& Marriott I 2009 Estrogens augment cell surface TLR4 expression on murine macrophages and regulate sepsis susceptibility in vivo. Endocrinology 150 3877-3884. (doi:10.1210/en. 2009-0098)

Rettew JA, McCall SH IV \& Marriott I 2010 GPR30/GPER-1 mediates rapid decreases in TLR4 expression on murine macrophages. Molecular and Cellular Endocrinology 328 87-92. (doi:10.1016/j.mce. 2010.07.017)

Ribas V, Drew BG, Le JA, Solymani T, Daraei P, Sitz D, Mohammad L, Henstridge DC, Febbraio M, Hewitt SC et al. 2011 Myeloid-specific estrogen a deficiency impairs metabolic homeostasis and accelerates atherosclerotic lesion development. PNAS 108 16457-16462. (doi:10.1073/pnas.1104533108)

Rossouw JE, Anderson GL, Prentice RL, LaCroix AZ, Kooperberg C, Stefanick ML, Jackson RD, Beresford SA, Howard BV, Johnson KC, Kotchen JM \& Ockene J 2002 Writing Group for the Women's Health Initiative Investigators. Risks and benefits of estrogen plus progestin in healthy postmenopausal women: principal results From the Women's Health Initiative randomized controlled trial. Journal of the American Medical Association 288 21-33.

Rossouw JE, Prentice RL, Manson JE, Wu L, Barad D, Barnabei VM, Ko M, LaCroix AZ, Margolis KL \& Stefanick ML 2007 Postmenopausal hormone therapy and risk of cardiovascular disease by age and years since menopause. Journal of the American Medical Association 297 1465-1477. (doi:10.1001/jama.297.13.1465)

Saintier D, Khanine V, Uzan B, Ea HK, de Vernejoul MC \& Cohen-Solal ME 2006 Estradiol inhibits adhesion and promotes apoptosis in murine osteoclasts in vitro. Journal of Steroid Biochemistry and Molecular Biology 99 165-173. (doi:10.1016/j.jsbmb.2006.01.009)

Saito S, Foegh ML, Motomura N, Lou H, Kent K \& Ramwell PW 1998 Estradiol inhibits allograft-inducible major histocompatibility complex class II antigen expression and transplant arteriosclerosis in the absence of immunosuppression. Transplantation 66 1424-1431. (doi:10.1097/00007890-199812150-00004)

Sandoval KE \& Witt KA 2011 Age and 17ß-estradiol effects on bloodbrain barrier tight junction and estrogen receptor proteins in ovariectomized rats. Microvascular Research 81 198-205. (doi:10.1016/j.mvr.2010.12.007)

Sarma U, Edwards M, Motoyoshi K \& Flanagan AM 1998 Inhibition of bone resorption by $17 \beta$-estradiol in human bone marrow cultures. Journal of Cellular Physiology 175 99-108. (doi:10.1002/(SICI) 1097-4652(199804) 175:1 < 99::AID-JCP11 > 3.0.CO;2-J)

Seeger H, Mueck AO \& Lippert TH 1999 Effect of estradiol metabolites on prostacyclin synthesis in human endothelial cell cultures. Life Sciences 65 167-170. (doi:10.1016/S0024-3205(99) 00383-5)

Seli E, Selam B, Mor G, Kayisli UA, Pehlivan T \& Arici A 2001 Estradiol regulates monocyte chemotactic protein-1 in human coronary artery smooth muscle cells: a mechanism for its antiatherogenic effect. Menopause 8 296-301. (doi:10.1097/00042192-20010700000013)

Seli E, Guzeloglu-Kayisli O, Kayisli UA, Kizilay G \& Arici A 2007 Estrogen increases apoptosis in the arterial wall in a murine atherosclerosis model. Fertility and Sterility 88 1190-1196. (doi:10.1016/j.fertnstert.2007.01.132)

Sengupta K, Banerjee S, Saxena NK \& Banerjee SK 2004 Thombospondin-1 disrupts estrogen-induced endothelial cell proliferation and migration and its expression is suppressed by estradiol. Molecular Cancer Research 2 150-158.

Sherman TS, Chambliss KL, Gibson LL, Pace MC, Mendelsohn ME, Pfister SL \& Shaul PW 2002 Estrogen acutely activates prostacyclin synthesis in ovine fetal pulmonary artery endothelium. American Journal of Respiratory Cell and Molecular Biology 26 610-616.

Simoncini T, De Caterina R \& Genazzani AR 1999 Selective estrogen receptor modulators: different actions on vascular cell adhesion molecule-1 (VCAM-1) expression in human endothelial cells. Journal of Clinical Endocrinology and Metabolism 84 815-818. (doi:10.1210/jc.84.2.815)

Simoncini T, Maffei S, Basta G, Barsacchi G, Genazzani AR, Liao JK \& De Caterina R 2000 Estrogens and glucocorticoids inhibit endothelial vascular cell adhesion molecule-1 expression by different transcriptional mechanisms. Circulation Research $\mathbf{8 7}$ 19-25.

Siracusa MC, Overstreet MG, Housseau F, Scott AL \& Klein SL 2008 $17 \beta$-Estradiol alters the activity of conventional and IFN-producing killer dendritic cells. Journal of Immunology 180 1423-1431.

Sivritas D, Becher MU, Ebrahimian T, Arfa O, Rapp S, Bohner A, Mueller CF, Umemura T, Wassmann S, Nickenig G et al. 2011 
Antiproliferative effect of estrogen in vascular smooth muscle cells is mediated by Kruppel-like factor- 4 and manganese superoxide dismutase. Basic Research in Cardiology 106 563-575. (doi:10.1007/ s00395-011-0174-z)

Sobrino A, Mata M, Laguna-Fernandez A, Novella S, Oviedo PJ, García-Pérez MA, Tarín JJ, Cano A \& Hermenegildo C 2009 Estradiol stimulates vasodilatory and metabolic pathways in cultured human endothelial cells. PLoS ONE 4 e8242. (doi:10.1371/journal. pone.0008242)

Sobrino A, Oviedo PJ, Novella S, Laguna-Fernandez A, Bueno C, García-Pérez MA, Tarín JJ, Cano A \& Hermenegildo C 2010 Estradiol selectively stimulates endothelial prostacyclin production through estrogen receptor- $\alpha$. Journal of Molecular Endocrinology $4 \mathbf{4}$ 237-246. (doi:10.1677/JME-09-0112)

Spyridopoulos I, Sullivan AB, Kearney M, Isner JM \& Losordo DW 1997 Estrogen-receptor-mediated inhibition of human endothelial cell apoptosis. Estradiol as a survival factor. Circulation 95 1505-1514.

Sribnick EA, Samantaray S, Das A, Smith J, Matzelle DD, Ray SK \& Banik NL 2010 Postinjury estrogen treatment of chronic spinal cord injury improves locomotor function in rats. Journal of Neuroscience Research 88 1738-1750.

Straub RH 2007 The complex role of estrogenes in inflammation. Endocrine Reviews 28 521-574. (doi:10.1210/er.2007-0001)

Strehlow K, Rotter S, Wassmann S, Adam O, Grohé C, Laufs K, Böhm M \& Nickenig G 2003 Modulation of antioxidant enzyme expression and function by estrogen. Circulation Research 93 170-177. (doi:10.1161/01.RES.0000082334.17947.11)

Su EJ, Lin ZH, Zeine R, Yin P, Reierstad S, Innes JE \& Bulun SE 2009 Estrogen receptor- $\beta$ mediates cyclooxygenase-2 expression and vascular prostanoid levels in human placental villous endothelial cells. American Journal of Obstetrics and Gynecology 200 427.e1-427.e8. (doi:10.1016/j.ajog.2009.01.025)

Subramanian M \& Shaha C 2009 Oestrogen modulates human macrophage apoptosis via differential signalling through oestrogen receptor- $\alpha$ and $\beta$. Journal of Cellular and Molecular Medicine 13 2317-2329. (doi:10.1111/j.1582-4934.2008.00679.x)

Sudoh N, Toba K, Akishita M, Ako J, Hashimoto M, Iijima K, Kim S, Liang YQ, Ohike Y, Watanabe T et al. 2001 Estrogen prevents oxidative stress-induced endothelial cell apoptosis in rats. Circulation 103 724-749.

Sulistiyani \& St Clair RW 1997 Effect of $17 \beta$-estradiol on metabolism of acetylated low-density lipoprotein by THP-1 macrophages in culture. Arteriosclerosis, Thrombosis, and Vascular Biology 17 1691-1700. (doi:10.1161/01.ATV.17.9.1691)

Sumanasekera WK, Sumanasekera GU, Mattingly KA, Dougherty SM, Keynton RS \& Klinge CM 2007 Estradiol and dihydrotestosterone regulate endothelial cell barrier function after hypergravity-induced alterations in MAPK activity. American Journal of Physiology. Cellular Physiology 293 C566-C573. (doi:10.1152/ajpcell.00418.2006)

Sun J, Ma X, Chen YX, Rayner K, Hibbert B, McNulty M, Dhaliwal B, Simard T, Ramirez D \& O'brien E 2011 Attenuation of atherogenesis via the anti-inflammatory effects of the selective estrogen receptor $\beta$ modulator 8 $\beta$-VE2. Journal of Cardiovascular Pharmacology 58 399-405. (doi:10.1097/FJC.0b013e318226bd16)

Suzuki A, Mizuno K, Ino Y, Okada M, Kikkawa F, Mizutani S \& Tomoda Y 1996 Effects of $17 \beta$-estradiol and progesterone on growth-factorinduced proliferation and migration in human female aortic smooth muscle cells in vitro. Cardiovascular Research 32 516-523.

Suzuki T, Shimizu T, Yu HP, Hsieh YC, Choudhry MA, Bland KI \& Chaudry IH 2007 Estrogen receptor- $\alpha$ predominantly mediates the salutary effects of $17 \beta$-estradiol on splenic macrophages following trauma-hemorrhage. American Journal of Physiology. Cellular Physiology 293 C978-C984. (doi:10.1152/ajpcell.00092.2007)

Suzuki T, Yu HP, Hsieh YC, Choudhry MA, Bland KI \& Chaudry IH 2008 Estrogen-mediated activation of non-genomic pathway improves macrophages cytokine production following traumahemorrhage. Journal of Cellular Physiology 214 662-672.

(doi:10.1002/jcp.21255)
Takahashi K, Ohmichi M, Yoshida M, Hisamoto K, Mabuchi S, Arimoto-Ishida E, Mori A, Tsutsumi S, Tasaka K, Murata Y et al. 2003 Both estrogen and raloxifene cause $G_{1}$ arrest of vascular smooth muscle cells. Journal of Endocrinology 178 319-329. (doi:10.1677/joe. $0.1780319)$

The Coronary Drug Project Research Group 1970 The Coronary Drug Project: initial findings leading to modifications of its research protocol. Journal of the American Medical Association 214 1303-1313. (doi:10.1001/jama.1970.03180070069012)

Thongngarm T, Jenkins JK, Ndebele K \& McMurray RW 2003 Estrogen and progesterone modulate monocyte cell cycle progression and apoptosis. American Journal of Reproductive Immunology 49 129-138. (doi:10.1034/j.1600-0897.2003.00015.x)

Thor D, Zhang R, Anderson L, Bose DD, Dubé GP \& Rahimian R 2010 Effects of $17 \beta$-estradiol on lipopolysacharride-induced intracellular adhesion molecule-1 mRNA expression and $\mathrm{Ca}^{2+}$ homeostasis alteration in human endothelial cells. Vascular Pharmacology $\mathbf{5 3}$ 230-238. (doi:10.1016/j.vph.2010.09.001)

Tse J, Martin-McNaulty B, Halks-Miller M, Kauser K, DelVecchio V, Vergona R, Sullivan ME \& Rubanyi GM 1999 Accelerated atherosclerosis and premature calcified cartilaginous metaplasia in the aorta of diabetic male Apo E knockout mice can be prevented by chronic treatment with 17ß-estradiol. Atherosclerosis 144 303-313. (doi:10.1016/S0021-9150(98)00325-6)

Tsuda M, Iwai M, Li JM, Li HS, Min LJ, Ide A, Okumura M, Suzuki J, Mogi M, Suzuki H et al. 2005 Inhibitory effects of AT1 receptor blocker, olmesartan, and estrogen on atherosclerosis via antioxidative stress. Hypertension 45 545-551. (doi:10.1161/01.HYP. 0000157409.88971.fc)

Umetani M \& Shaul PW 2011 27-Hydroxycholesterol: the first identified endogenous SERM. Trends in Endocrinology and Metabolism 22 130-135. (doi:10.1016/j.tem.2011.01.003)

Vegeto E, Ghisletti S, Meda C, Etteri S, Belcredito S \& Maggi A 2004 Regulation of the lipopolysaccharide signal transduction pathway by $17 \beta$-estradiol in macrophage cells. Journal of Steroid Biochemistry and Molecular Biology 91 59-66. (doi:10.1016/j.jsbmb.2004.02.004)

Villablanca A, Lubahn D, Shelby L, Lloyd K \& Barthold S 2004 Susceptibility to early atherosclerosis in male mice is mediated by estrogen receptor $\alpha$. Arteriosclerosis, Thrombosis, and Vascular Biology 24 1055-1061. (doi:10.1161/01.ATV.0000130467.65290.d4)

Villablanca AC, Tenwolde A, Lee M, Huck M, Mumenthaler S \& Rutledge JC 2009 17 $\beta$-Estradiol prevents early-stage atherosclerosis in estrogen receptor- $\alpha$ deficient female mice. Journal of Cardiovascular Translational Research 2 289-299. (doi:10.1007/s12265-0099103-z)

Wagner AH, Schroeter MR \& Hecker M 2001 17ß-Estradiol inhibition of NADPH oxidase expression in human endothelial cells. FASEB Journal 15 2121-2130. (doi:10.1096/fj.01-0123com)

Wang TH, Xiang QL, Chen JW, Pan H \& Cui YH 2007 Raloxifene plus $17 \beta$-estradiol inhibits proliferation of primary cultured vascular smooth muscle cells and human mammary endothelial cells via the janus kinase/signal transducer and activator of transcription3 cascade. European Journal of Pharmacology 561 7-13. (doi:10.1016/j. ejphar.2007.01.026)

Wang J, Zhang R, Xu Y, Zhou H, Wang B \& Li S 2008 Genistein inhibits the development of atherosclerosis via inhibiting NF-kappaB and VCAM-1 expression in LDLR knockout mice. Canadian Journal of Physiology and Pharmacology 86 777-7784. (doi:10.1139/Y08-085)

Wassmann K, Wassmann S \& Nickenig G 2005 Progesterone antagonizes the vasoprotective effect of estrogen on antioxidant enzyme expression and function. Circulation Research 97 1046-1054. (doi:10.1161/01.RES.0000188212.57180.55)

Williams MR, Dawood T, Ling S, Dai A, Lew R, Myles K, Funder JW, Sudhir K \& Komesaroff PA 2004 Dehydroepiandrosterone increases endothelial cell proliferation in vitro and improves endothelial function in vivo by mechanisms independent of androgen and estrogen receptors. Journal of Clinical Endocrinology and Metabolism $\mathbf{8 9}$ 4708-47015. (doi:10.1210/jc.2003-031560) 
Wilson ME, Sengoku T \& Allred KF 2008 Estrogen prevents cholesteryl ester accumulation in macrophages induced by the HIV protease inhibitor ritonavir. Journal of Cellular Biochemistry 103 1598-1606. (doi:10.1002/jcb.21546)

Wing LY, Chen YC, Shih YY, Cheng JC, Lin YJ \& Jiang MJ 2009 Effects of oral estrogen on aortic ROS-generating and -scavenging enzymes and atherosclerosis in apoE-deficient mice. Experimental Biology and Medicine 234 1037-1046. (doi:10.3181/0811-RM-332)

Xing D, Feng W, Miller AP, Weathington NM, Chen YF, Novak L, Blalock JE \& Oparil S 2007 Estrogen modulates TNF- $\alpha$-induced inflammatory responses in rat aortic smooth muscle cells through estrogen receptor- $\beta$ activation. American Journal of Physiology. Heart and Circulatory Physiology 292 H2607-H2612. (doi:10.1152/ajpheart. $01107.2006)$

Xiu-li W, Wen-jun C, Hui-hua D, Su-ping H \& Shi-long F 2009 ERB-041, a selective ER $\beta$ agonist, inhibits iNOS production in LPS-activated peritoneal macrophages of endometriosis via suppression of NF-kappaB activation. Molecular Immunology 46 2413-2418. (doi:10.1016/j.molimm.2009.04.014)

Yang Z, Cheng B, Song J, Wan Y, Wang Q, Cheng B \& Chen X 2007 Estrogen accelerates $G_{1}$ to $S$ phase transition and induces $\mathrm{G}_{2} / \mathrm{M}$ phase-predominant apoptosis in synthetic vascular smooth muscle cells. International Journal of Cardiology 118 381-388. (doi:10.1016/j. ijcard.2006.07.049)

Yao PM \& Tabas I 2000 Free cholesterol loading of macrophages induces apoptosis involving the fas pathway. Journal of Biological Chemistry 275 23807-23813. (doi:10.1074/jbc.M00 2087200)

Ye L, Martin TA, Parr C, Harrison GM, Mansel RE \& Jiang WG 2003 Biphasic effects of $17-\beta$-estradiol on expression of occludin and transendothelial resistance and paracellular permeability in human vascular endothelial cells. Journal of Cellular Physiology 196 362-369. (doi:10.1002/jcp.10315)

Yoon BK, Oh WJ, Kessel B, Roh CR, Choi D, Lee JH \& Kim DK 2001 $17 \beta$-Estradiol inhibits proliferation of cultured vascular smooth muscle cells induced by lysophosphatidylcholine via a nongenomic antioxidant mechanism. Menopause 8 58-64. (doi:10.1097/ 00042192-200101000-00010)
Yoshitake J, Kato K, Yoshioka D, Sueishi Y, Sawa T, Akaike T \& Yoshimura T 2008 Suppression of NO production and 8-nitroguanosine formation by phenol-containing endocrine-disrupting chemicals in LPS-stimulated macrophages: involvement of estrogen receptor-dependent or -independent pathways. Nitric Oxide 18 223-228. (doi:10.1016/j.niox.2008.01.003)

Yu J, Eto M, Akishita M, Okabe T \& Ouchi Y 2009 A selective estrogen receptor modulator inhibits TNF- $\alpha$-induced apoptosis by activating ERK1/2 signaling pathway in vascular endothelial cells. Vascular Pharmacology 51 21-28. (doi:10.1016/j.vph.2009.01.003)

Yuan Y, Shimizu I, Shen M, Aoyagi E, Takenaka H, Itagaki T, Urata M, Sannomiya K, Kohno N, Tamaki K et al. 2008 Effects of estradiol and progesterone on the proinflammatory cytokine production by mononuclear cells from patients with chronic hepatitis C. World Journal of Gastroenterology 14 2200-2207. (doi:10.3748/wjg.14. 2200)

Zacharia LC, Gogos JA, Karayiorgou M, Jackson EK, Gillespie DG, Barchiesi F \& Dubey RK 2003 Methoxyestradiols mediate the antimitogenic effects of $17 \beta$-estradiol. Circulation 108 2974-2978. (doi:10.1161/01.CIR.0000106900.66354.30)

Zacharia LC, Piche CA, Fielding RM, Holland KM, Allison SD, Dubey RK \& Jackson EK 2004 2-Hydroxyestradiol is a prodrug of 2-methoxyestradiol. Journal of Pharmacology and Experimental Therapeutics 309 1093-1097. (doi:10.1124/jpet.103.062505)

Zhang HH, Feng L, Livnat I, Hoh JK, Shim JY, Liao WX \& Chen DB 2010 Estradiol-17 $\beta$ stimulates specific receptor and endogenous nitric oxide-dependent dynamic endothelial protein $S$-nitrosylation: analysis of endothelial nitrosyl-proteome. Endocrinology 151 3874-3887. (doi:10.1210/en.2009-1356)

Zhang HH, Feng L, Wang W, Magness RR \& Chen DB 2012 Estrogenresponsive nitroso-proteome in uterine artery endothelial cells: role of endothelial nitric oxide synthase and estrogen receptor- $\beta$. Journal of Cellular Physiology 227 146-159. (doi:10.1002/jcp.22712)

Received in final form 15 February 2012

Accepted 20 February 2012

Made available online as an Accepted Preprint 20 February 2012 